\title{
Potential siliceous sources during Prehistory: Results of prospecting in the East margin of the Ebro Basin (NE Iberian Peninsula)
}

\author{
María Soto ${ }^{1-2}$, Bruno Gómez de Soler ${ }^{1-2}$, Josep Vallverdú ${ }^{1-2}$ and \\ Manuel Vaquero ${ }^{2-1}$
}

1. Institut Català de Paleoecologia Humana i Evolució Social (IPHES). IPHES. C/Marcel-lí Domingo s/n. Edifici W3. Campus Sesceslades-URV.43007 Tarragona, Spain.

2. Area de Prehistòria, Universitat Rovira i Virgili. Avinguda Catalunya, 35. 43002 Tarragona, Spain. Email: Soto: sotoquesadamaria@gmail.com; Gómez de Soler: bgomez@iphes.cat; Vallverdú: jvallverdu@iphes.cat; Vaquero: manuel.vaquero@urv.net

\begin{abstract}
:
We present the results of prospecting in the NE of the Iberian Peninsula, with the aim of identifying the siliceous sources potentially used by the populations that occupied the marginal basins of the Ebro depression during the Middle and Upper Palaeolithic.

We intend to define the main characteristics of the cherts in the region studied, taking into account the palaeoenvironment in which silicifications are mainly formed, and the premise that siliceous rocks acquire the attributes of enclosing rocks.

The cherts studied are the products of early diagenesis by replacement of carbonate and evaporite sediments. Petrological analyses show that they are made up of microquartz, with high proportion of fibrous forms silica, carbonates, ferric oxides and evaporite relicts. In the future, these characteristics will be useful for ascribing archaeological materials in both geological and geographical terms.
\end{abstract}

Keywords: lithic raw materials; chert characterisation; Ebro Basin; depositional models

\begin{abstract}
:
Presentamos los resultados de las prospecciones realizadas en el NE de la Península Ibérica, con el objetivo de localizar las áreas fuente silíceas potenciales para la captación de los paleo-pobladores que ocuparon las cuencas marginales de la depresión del Ebro durante el Paleolítico medio y superior.

Definiremos los principales caracteres de los sílex de la región estudiada, teniendo en cuenta el paleoambiente de los afloramientos y con la premisa que los sílex adquieren los atributos de la roca encajante.

Los sílex estudiados son producto de una diagénesis temprana por reemplazamiento de sedimentos carbonatados y evaporíticos. Los análisis petrológicos muestran que estos están formados por microcuarzo, con altas proporciones de sílice fibrosa, carbonatos, óxidos de hierro y relictos evaporíticos. Estos caracteres serán útiles para la posterior adscripción geológica y geográfica de los conjuntos arqueológicos.
\end{abstract}

Published by the School of History, Classics and Archaeology, University of Edinburgh ISSN: 2055-0472. URL: http://journals.ed.ac.uk/lithicstudies/

This work is licensed under a Creative Commons Attribution 2.5 UK: Scotland License. 
Keywords: materias primas líticas; caracterización del sílex; Cuenca del Ebro; modelos deposicionales

\section{Introduction}

Prospecting in the NE of the Iberian Peninsula was the first step in identifying the chert sources potentially frequented by the population that occupied the marginal basins of the Ebro depression during the Middle and Upper Palaeolithic.

Since the beginning of the twentieth century many archaeological excavations have been carried out in the area studied, revealing an archaeological record that stretches from the Lower to Upper Palaeolithic. The results of several excavations have confirmed a discontinuous but intensive occupation of the area from Lower to Final Upper Palaeolithic. (See Figure 1.)

The abundant evidence of diachronic occupation and the intensive use of chert as raw material in this region justify developing an abiotic resource project. This work represents part of two authors' $\mathrm{PhD}$ research focalized in the study of raw material usage and mobility patterns of six archaeological sites (Abric Romaní (Capellades), Molí del Salt (Vimbodí i Poblet), Balma de la Vall (Montblanc), St. Gregori (Falset), Cova de les Borres (La Febró) and Picamoixons (Picamoixons)) located at the central part of the Ebro basin margin and ranging from Middle to Upper Palaelolithic.

The aim of this research was to locate the existing chert sources in the region defined by Catalan Coast Ranges (CCR), and the Ódena (OB) and Barberà Basins (BB), and to characterise the potential raw materials. Locating and characterising geological chert samples will provide objective criteria for establishing the provisioning area of the archaeological assemblages in the future.

To accomplish these objectives, an intensive programme of geoarchaeological prospecting, sampling and characterising the depositional system was carried out. A reference collection of chert samples was studied both macro- and microscopically, using textural, mineralogical and modal criteria. Analysis had been performed through $a$ visu description, using a stereoscopic microscope, and thin-sections observations with a petrographic microscope. To complement these studies, we also used a scanning electron microscope and $\mathrm{X}$-ray diffraction.

\section{Geological Settings}

The area studied consists of three main structural units: the Central Catalan Depression, corresponding to the distal zone of the Ebro Basin, and made up of the Òdena and Barberà Basins; the central and southern sector of Catalan Coast Ranges and Penedès Depression.

The lower levels of the Catalan Coast Ranges are made up of: quartz ledges, slates and schists from Palaeozoic era. These are covered by Mesozoic limestones, dolomites, occasional gypsums, clays and sandstones (Triassic and Jurassic). The Central Catalan Depression is made up of an alternation of Cenozoic lutites, gypsum, marls, limestones and conglomerates (Palaeogene). Finally, detritus materials from Pliocene and Quaternary sediments form the Penedès Depression.

Excluding Pleistocene fluvial terraces chert outcrops were located in Early and Upper Muschelkalk (Triassic), Thanetian (Upper Palaeogene), Lutetian, Bartonian and Priabonian (Middle and Upper Eocene), Lower Oligocene and Pliocene deposits. (See Figure 2.) 


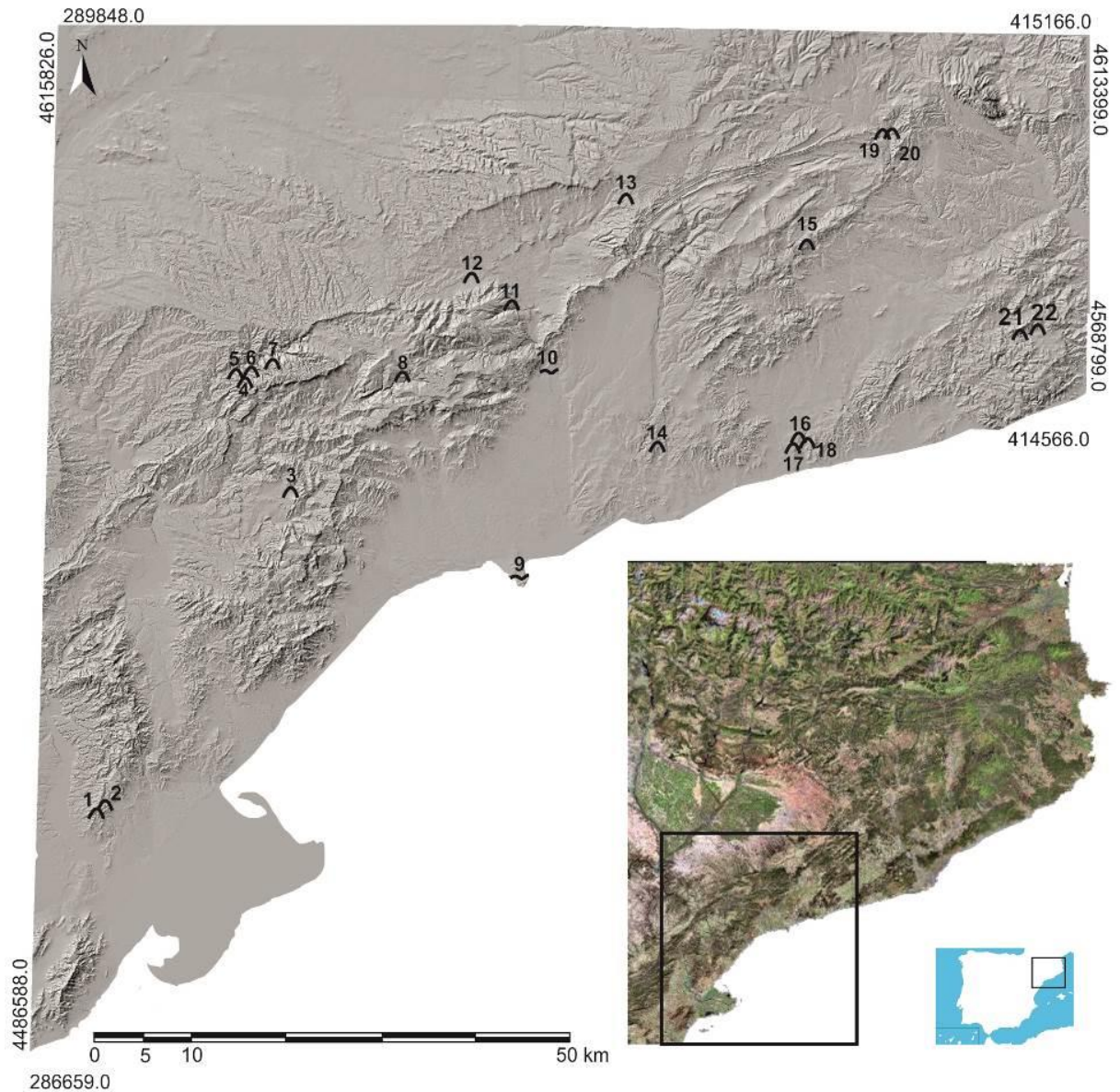

Figure 1. Elevation Digital Model of the studied area (obtained from 1:25000 topographical maps www.icc.cat) with the location of different sites. 31N UTM with ETRS89 Datum. $\cap$ Cave and rockshelters sites $\sim$ Open-air sites.1. Cova del Vidre, 2. Clot de l'Hospital, 3. Sant Gregori, 4. Abric dels Colls, 5. Hort de la Boquera, 6. Abric del Filador, 7. Balma de l'Auferí, 8. Cova de Les Borres, 9. Camping de Salou, 10. Picamoixons, 11. Balma de la Vall, 12. Molí del Salt, 13. Font Voltada, 14. La Cativera, 15. Cova de La Guineu, 16. Cova Foradada, 17. Cova de Mas Romeu, 18. Balma de la Griera, 19. Abric Agut, 20. Abric Romaní, 21. Cova San Sadurní, 22. Coveta del Marge del Moro.

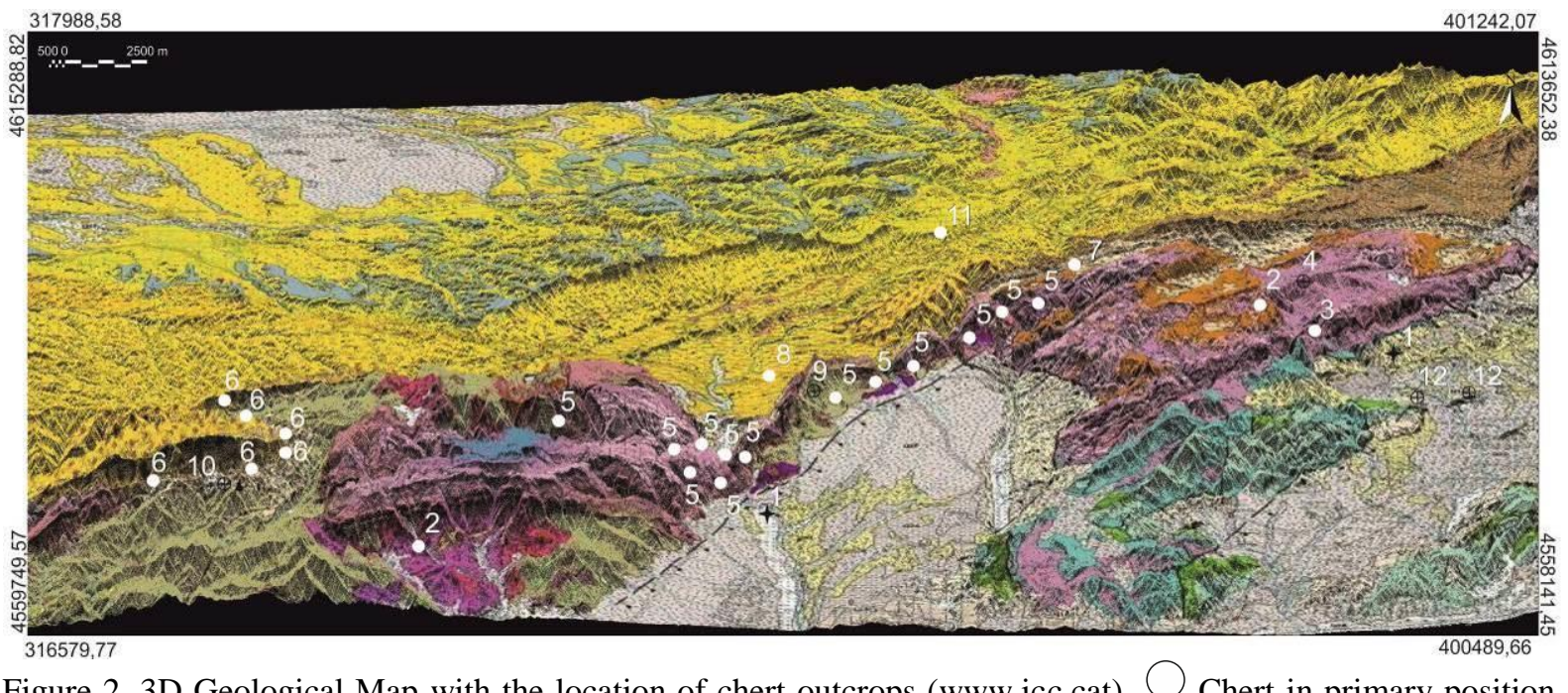

Figure 2. 3D Geological Map with the location of chert outcrops (www.icc.cat). $\bigcirc$ Chert in primary position.

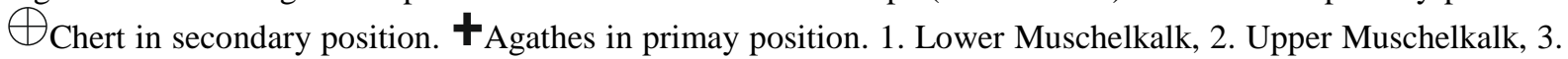
Mediona Fm., 4. Pobla de Claramunt Fm., 5. Valldeperes Fm., 6. Ulldemolins Fm., 7. St. Martí de Tous Fm., 8. Pira Fm., 9. St. Miquel Fm., 10. Balncafort Fm., 11. Montmaneu Fm., 12. Guixeras Serie. 


\section{Methods}

\subsection{Prospecting}

A $30-\mathrm{km}$ radius from each archaeological site was defined as the area to be prospected, based on the numerous archaeological and ethnographical studies about lithic procurement strategies (Binford 1982; Turq 1989; Geneste 1992; Féblot-Augustins 1999).

By compiling the geological bibliography regarding potential raw material outcrops and using the cartographic resources (geological maps, ortophotos, aerial photographs and satellite images) available for the areas of interest, we were able to make a-priori choices as to the principal areas to examine.

Several chert outcrops were located during the field prospecting campaigns and registered in a database containing the main descriptive characteristics - location, accessibility, geological and lithostratigraphical context, raw material present and possible evidences of human exploitation (Masson 1979; Demars 1982; Tarriño \& Ullibarri 1992; Bressy 2003).

Location data was imported as a structured vectorial format from a GPS into a digitalized geological and topological map (1:50000) with the aim of creating a specialised siliceous rock cartography. Each outcrop was also systematically sampled, and the siliceous material collected was used to create a complete lithotheque that comprises the availability and variety of the representative chert in the region.

We subjected the components of this regional reference collection to several macro- and micro-analyses, in order to determine the principal characteristics of geological chert, the correlations with the lithic material from the archaeological assemblages, and consequently the interactional dynamics between the population and the landscape (Mangado 2000; Terradas 2001; Terrades \& Molist 2002; Mangado 2006; Bustillo et al. 2009).

\subsection{Characterisation of chert}

\subsubsection{Macroscopic analysis}

This analytical technique consists of describing the morphoscopic features of lithic materials by means of $a$ visu observations and the use of a stereoscopic microscope (ZEISS Stemi DV4 8-32x).

Macroscopic analysis had been the most employed analysis because of its nondestructive nature and its relative simplicity. It is nevertheless considered to be just the basis of raw materials research, and must be combined with other techniques to form a multiscale methodological approach to defining the discriminating characteristics for determining rock genesis.

The parameters established for macroscopic analysis are divided into two groups, based on the internal or external characteristics of the rocks. The external characteristics studied were: I) the morphology of the support (nodular, block, cobble, tabular or fragment) and size (centimetric to metric) of the samples, and II) the cortical zone, determining the colour, thickness, roundness index of the outer area of chert and nature of enclosed rock.

The following internal features were analysed: I) the colour and its distribution, as indicative of sedimentary environments and their changing conditions (The geological society of America 1991). II) Transparency, since it is a criterion for identifying genetic environments. III) Texture, related to the roughness of the surface to touch (very fine, fine, medium coarse, coarse). IV) Sedimentary structures, as indicative of depositional environments. V) Presence of fissures and joints. VI) Patina, as a postdepositional alteration. VII) Presence of impurities, such as geodes, oxides or carbonates. VIII) And finally, the microfossils content, such as spicules, gastropods, bivalves or foraminifera observable $a$ visu 
(Folk 1952; Schmalz 1960; Folk 1974; Masson 1979; Demars 1982; Bignot 1988; Mangado 2000; Terradas et al. 2006; Gómez de Soler 2007; Fernandes et al. 2010; García-Antón 2010; Soto 2010).

\subsubsection{Microscopic analysis}

\subsubsection{Thin sections}

It consists of observing thin sections ( $30 \mu \mathrm{m}$ thickness) of the cherts with a Polarizing Microscope (Olympus BHSP 40-400x), in order to determine their mineralogical composition and textural features and impurities they contain.

Microscopic analysis describes the textural and mineralogical composition of samples by defining I) texture of a quartz (megaquartz, microquartz, cryptocrystalline quartz, chalcedonite, quartzine and lutecite), mixed forms, opal and moganite, and their estimated percentages; II) the presence or absences of non epigenic relict minerals such as carbonates, oxides, sulfates or terrigenous minerals; III) the authigenic minerals, as sulphides, carbonates or quartz (Folk 1952; 1974; Bustillo 1982; Tarriño 2006; Boggs 2009; Bustillo 2010).

\subsubsection{Scanning Electron Microscope and $\mu-X R D$}

Those samples that provide insufficient information under macroscopic and thin sections observation were also observed under the Scanning Electron Microscope (FEI Quanta 600). This observation is non-destructive and fast, and makes it possible the grain size, the typology of the cortical zone and the possible origin and make a preliminary identification of the specimen's mineral composition (Fernandes 2007 ; García-Antón 2010; Fernandes 2012).

For certain cherts, petrological characterisation by Micro X-Ray Diffraction (BrukerAXS D8-Discover diffractometer) was also carried out. This technique consists in obtaining a diffraction pattern from the interaction between X-Ray beam and the electrons of the sample. The resulted diagram makes it possible to identify the different mineralogical phases (Flörke et al. 1982; Heaney 1995; Morant 1998; Grégoire 2001). This technique assisted us in identifying whether dolomite or calcite in those samples for which identification using the thin section technique was difficult.

Table 1. Geological formations with chert and its geochronological adscription.

\begin{tabular}{|c|c|c|c|}
\hline PERIOD & ЕPOCH & AGE & FORMATION WITH CHERT \\
\hline PLIOCENE & & & 15. Guixera's Serie \\
\hline \multirow{6}{*}{ PALEOGENE } & OLIGOCENE & Stampian & $\begin{array}{l}\text { 14. Montmaneu Fm. } \\
\text { 13. Blancafort Fm. } \\
\text { 12. St. Miquel Fm. } \\
\text { 11. Pira Fm. }\end{array}$ \\
\hline & & Priabonian & $\begin{array}{l}\text { 10. St.Martí de Tous Fm. } \\
\text { 9. Montblanc Fm. }\end{array}$ \\
\hline & & Bartonian & $\begin{array}{l}\text { 8. Morera Fm. } \\
\text { 7. Bosc d'en Borràs Fm }\end{array}$ \\
\hline & EOCENE & & 6. Ulldemolins Complex \\
\hline & & Lutetian & $\begin{array}{l}\text { 5. Valldeperes Fm. } \\
\text { 4. Pobla de Claramunt Fm. }\end{array}$ \\
\hline & PALEOCENE & Thanetian & 3. Mediona Fm \\
\hline TRIASSIC & & & $\begin{array}{l}\text { 2. Upper Mushelkalk } \\
\text { 1. LowerMuschelkalk }\end{array}$ \\
\hline
\end{tabular}




\section{Results}

\subsection{Chert outcrops}

During our prospecting programme more than 40 chert outcrops were located and sampled. They correspond to 15 different geological formations (Table 1), dating from the Triassic to Pliocene (Morant 1998; Gómez de Soler 2007; Soto 2010; Carbonell 2012).

\section{Lower Muschelkalk.}

This formation, included in the Triassic levels of the Prelittoral range (Catalan Coast Ranges), is characterised by dolomitic limestone and tabulated dolomites. In the outcrop located around the town of La Mussara, both these lithologies contain chert and are related to a coastal environment of lagoon formations ((Virgili 1958; Sopeña et al. 1983; Marzo \& Calvet 1985; Bofarull 1997; Morant 1998; Gómez de Soler 2009; Carbonell 2012).

\section{Upper Muschelkalk.}

This formation also appears in the Prelittoral range. It is composed of an association of limestones, dolomites and marls, related to a depositional facies of shallow marine water. Cherts found in this formation, near the town of La Riba town, are described as agate and are included in undulated limestone lithologies (Virgili 1958; Sopeña et al. 1983).

\section{Mediona formation.}

This formation is characterized by the presence of Vidaliella gerundensis (Bullimus), which suggests the Thanetian era (Upper Palaeocene) (Anadón 1978; Anadón \& Marzo 1986; Colldeforns et al. 1994; Ortí et al. 2007) It is geographically discontinuous and composed of stretches of red lutite of continental, fluvial and lacustrine origin, inserted in calcrete levels with chert of edaphic-origin, which appears in small quantities. The chert-bearing deposits were documented at St. Joan de Mediona, near St. Quintí de Mediona creek (Gómez de Soler 2009).

\section{Ulldemolins Complex.}

This lithostratigraphic complex is located around the town of Ulldemolins, and is dated as Thanetian-Lutetian age. It is characterized by: a carbonate basal section; a lower evaporite association, made up of nodular and massive gypsiferous levels; a carbonate medial section of lutites and limestones; an upper level of laminated and massive gypsum; and finally a terminal sandstone sequence. Lithological association describes a sedimentary sabkha type evaporitic system. Nodular and meganodular chert are abundant in both gypsiferous and carbonate facies (Colombo 1986; Ortí 1989; Colombo \& Vergés 1992; Colombo \& Escarrè 1994; Doce \& Alcobé 1997; Soto et al. 2011; Ortí 2012).

\section{Morera formation.}

This is defined by carbonated materials (Thanetian-Lutetian age), is located above the Ulldemolins Complex, and is considered to be the lateral equivalent of the Bosc d'en Borràs formation. The lithology is described as mudstone limestones with nodular chert and intercalated red lutites. It is also associated with a lacustrine carbonate deposition, having a permanent water-sheet (Colombo 1986; Anadón et al. 1989; Colombo \& Escarrè 1994; Soto et al. 2011).

\section{Pobla de Claramunt formation.}

This is an Upper Lutetian-Lower Bartonian formation (Middle Eocene) (Anadón \& Marzo 1986), made up of red sandstones and lutite series with thick conglomerate levels. The formation is fluvial in origin, corresponding to distal areas of alluvial fans. Chert nodules, 
although very scarce, were documented in the conglomerates located between Carme and La Pobla de Claramunt (Morant 1998; Gómez de Soler 2007; Carbonell 2012).

\section{Valldeperes formation.}

These $55 \mathrm{~km}$ stretches located between the towns of Vilaverd and Valldeperes correspond to the Bartonian age (Ortí et al. 2007). They are composed by carbonate (dolomites, limestones and marls) and gypsiferous facies. In extensive areas, nodular gysums developed in dolomitic stretches characterise the dominant lithofacies. Carbonated facies are related to a lacustrine environment with a stable water-sheet. Gypsiferous facies correspond to a saline lake above lutitic plain. We focussed our attention on the areas of the towns of Vilaverd, Lilla, Vallespinosa and Valldeperes, where chert is abundant (Anadón 1978; Anadón \& Marzo 1986; Ortí 1990; Bofarull 1997; Morant 1998; Gómez de Soler 2009; Soto et al. 2011).

\section{Bosc d'en Borràs formation.}

Dated as Bartonian, it is located between the towns of Vilaverd and Montblanc, above the eastern sector of Valldeperes Fm. Micritical and biomicritical limestones and marls, related to kilometric lacustrine and palustrine depositional environment, compose this formation. Meganodular chert is an abundant product held in these carbonate levels (Colombo 1986; Colldeforns et al. 1994; Ortí et al. 2007; Soto et al. 2011).

\section{Montblanc formation.}

It is dated as Bartonian-Stampian, and located around the eponymous town. It is made up of red lutites, detritic facies, sandstones and conglomerates in which cherts are frequently found. This association of facies is related to an alluvial system in which both processes of both drying out and wetting occurred (Colldeforns et al. 1994; Ortí et al. 2007).

\section{St. Martí de Tous formation.}

Defined by Colldeforns (Colldeforns et al. 1994) as an Upper Priabonian-Stampian formation, it is made up of a 50 m-thick succession of grey sandy lutites with ripple lamination that contain metric sandstone levels with cross- stratification and conglomerate lenses. The sedimentary model is associated with a lacustrine model. Three stretches with abundant chert have been located in primary position around the town of St. Martí of Tous (Gómez de Soler 2009; Carbonell 2012).

\section{Pira formation.}

Dated as Priabonian-Stampian, this formation appears between the towns of L'Espluga del Francolí and Sarral. It is composedof levels of red lutites with nodular and laminated gypsums, and then marls, limestones and conglomerates form the last level. The sedimentary model is associated with an occasional exchange zone, in which dry and moisture-based processes occurred. Chert has been described as frequently found in gypsiferous and marl facies (Ortí et al. 2007).

\section{Sant Miquel Formation.}

Sandstones, lutites and conglomerates with scarce cherts compose Sant Miquel Formation, the lateral equivalent of Pira fm. The lithologies are associated with depositions in river beds. 


\section{Blancafort formation.}

This is made up of lutite, sand and gypsum levels dated to the Stampian age. The depositional model associated with it is a distal alluvial fan. Chert is scarce in this formation (Ortí et al. 2007).

\section{Montmaneu formation.}

This formation is comprised of deposits from the lacustrine system of La Segarra (Anadón and Marzo 1986). It is made up of $120 \mathrm{~m}$ of stratified light grey limestone with nodular levels of stratified chert from the Lower Oligocene age. Chert is located in the Panadella-Montmaneu area (Anadón et al. 1989; Colldeforns et al. 1994).

\section{Guixera series.}

This is a series that has been dated to the Pliocene, consisting of conglomerates in banks, and inserted amongst them, packets of red lutite with abundant indications of edaphogenesis. In recent studies, it has been suggested that the erosion of the Ebro basin sediments originated these sediments during the Miocene (Gallart 1981; Gómez de Soler 2009). Chert located in the conglomerates is found in the villages of St. Quintí de Mediona and St. Pere de Riudevitlles (Carbonell et al. 1992; Vaquero 1997; Morant 1998; Carbonell 2012). The origin of the chert nodules was the evaporite deposits in the Valldeperes formation and they were later deposited in the Penedès Depression.

Our prospecting programme determined the origins of the cherts, by defining the sedimentary model of the deposits where these were formed.

The conditions of host rocks in terms of genesis and deposition affect silicification. By understanding this process it is possible to define the main attributes (i.e. the composition and the sedimentary structures preserved in chert). Our prospecting programme will make it possible to propose the origins of cherts, by defining six different sedimentary models (Gómez de Soler 2009; Soto et al. 2011; Carbonell 2012). (See Figure 3.)

Triassic silicifications are associated with calcareous-dolomitic lithologies, from shallow platforms with fluvial deposits. This sedimentary model is suitable with tidal and intertidal conditions related to episodes of Tethys transgression and therefore dated to the Lower and Upper Muschelkalk eras. Chert nodules are here a product of a diagenetic syn-sedimentary replacement of carbonate materials by biogenic silica.

Thanetian silicifications are associated with carbonatic and lutitic materials from a continental deposition following the lacustrine or fluvial sedimentary models. Chert diagenesis depends on these models and includes syndiagenetic and epidiagenetic processes of replacing the previous lithofacies.

Lutetian silicifications are associated with red lutites and gypsum, related to an expansive endorheic evaporite deposit of the sabhka type. Cherts are generated by microquartz precipitation after the dissolution of evaporite minerals in sabkhas. They are therefore likely to contain gypsum pseudomorphs and lenght-slow chalcedony; quartzine or lutecite.

Bartonian cherts are related to consolidated carbonates and massive marls associated with a platform depositional model. Cherts are the products of a partial replacement of carbonate materials submerged under a sheet of water, and must present length-fast silica in fibrous forms. Cherts located at the basal zone of the formations present some evaporitic features. These are probably resedimented after an erosive process located on the top of lutetian formations.

Lower Oligocene silicifications are located in brines (Sannonian) and lacustrine (Stampian) deposits. Chert nodules are a product of the replacement of buried sediments. 
The only Pliocene formation with chert has detrital origins (located in conglomerates). It means that chert pebbles in secondary position derive mainly from Palaeogene formations. Consequently they share the same attributes that characterize the previous formation and are only distinguished by the roundness of the cortex.
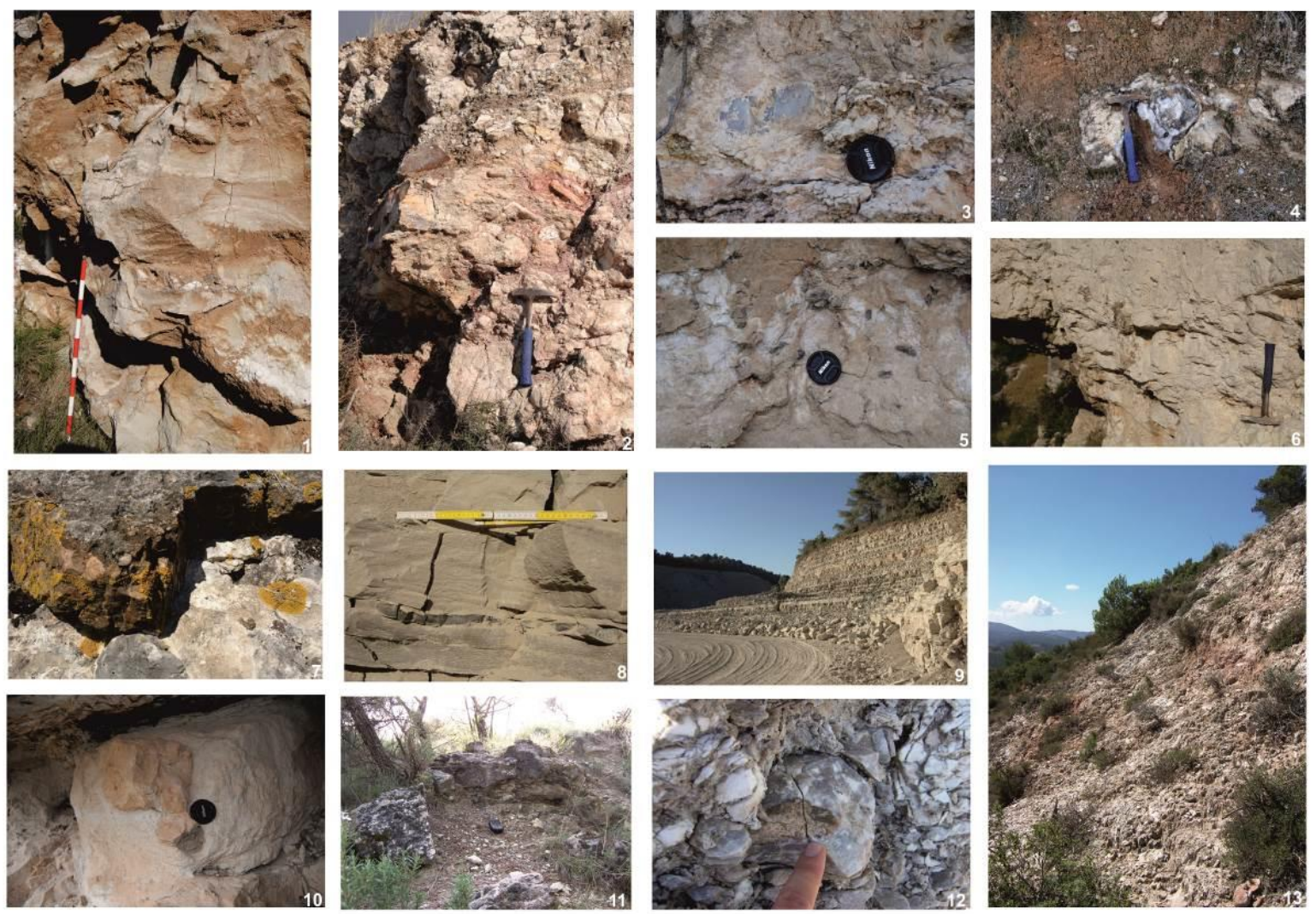

Figure 3. Some of prospected outcrops. Different silicifications enclosed in evaporitic gypsums and red lutites (Valldeperes Fm. [Images 1, 2, 12 \& 13] Ulldemolins Complex [3,4] Pira Fm. [5]); and chert nodules enclosed in limestones and dolomites (Bosc d'en Borras Fm. [6], St Miquel Fm [7] Valldeperes Fm. 8, 9, 10\& 11]).

\subsection{Geological chert characterisation}

\section{Lower \& Upper Muschelkalk chert.}

These have regular rounded morphologies, defined as nodules of maximum length 10-30 $\mathrm{cm}$ with calcareous grey cortex about 5-10 mm wide, and dark grey colours (Light Bluish Gray 7/1 and 8/1) forming Liesengang rings. These are usually opaque, with allochemical elements, and have white patina.

Petrological analysis of Lower Muschelkalk samples shows a micro-biosparitic texture, with Liesengang rings, caused by a cycle of supersaturation-nucleation-depletion of silica during the deposition. These Muschelkalk samples were mainly formed from bioclastic, rhomboidal and micritic dolomites (approximately 68\%), demonstrating that they are silicified limestone. The remaining percentage $(30 \%)$ is related to isometric and undulant microquartz, which fills cavities and some microfossils (especially gastropods and and charophyta). Opaque minerals are also present $(2 \%)$.

The Upper Muschelkalk cherts are composed of a biomicrite matrix. The main component is microquartz (48\%), presented in its isometric, but mostly its undulating forms, that fill and are inbetween the fossils. Bioclastic, rhomboidals and micritic carbonates $(40 \%)$ 
prior to the silicification, are also present in the matrix and as part of microfossils. Palisadic and mosaic-forming megaquartz make up $10 \%$ of the composition.

Micro-XRD confirms that the Muschelkalk samples are composed mainly of quartz and dolomite. (See Figure 4.)

\section{Thanetian chert.}

Appears in angular breccia forms in primary position, although in small quantities of centimetric size, with a maximum thickness of $5 \mathrm{~cm}$. Patina and concretion are absent in the samples collected. The cortex is calcareous, laminated and micritic, generally without transition and with a thickness of $1.5 \mathrm{~mm}$. The siliceous body is opaque and dark grey-brown (Dark grayish brown 10 YR 4/2) in colour, with reddish tones (Dark reddish brown 5YR 3/2) due to the presence of oxidation. It is coarse to the touch and breaks with a conchoidal fracture with many fissures, which makes it somewhat difficult to knap. Many iron oxides and crystal growths are described. It has a laminated sedimentary structure.

A distinctive feature is that petrological analysis shows alternating carbonate and quartz laminations. Composed mainly of in-puzzle, and mosaic macroquartz (39\%), the biggest crystals are described filling cavities and fissures. Micritic and -less frequently- rhomboidal carbonates are described in a presence of $35 \%$. Isometric microquartz (20\%), length- fast chalcedony $(1 \%)$ and ferric oxides are also present.

$\mu$-XRD shows that quartz, calcite and dolomite are present. (See Figure 5.)

\section{Eocene cherts}

Eocene cherts are located in evaporite (Lutetian) and calcareous (Bartonian) formations.

\section{Lutetian cherts}

Lutetian cherts are presented as nodular or fragments supports among $10-50 \mathrm{~cm}$ of length. Their cortexes have an evaporitic origin, orangey in colour (between Grayish Orange 10YR 7/4, Dark Yellowish Orange 10YR 6/6 and Very Pale Orange 10 YR 8/2) and the width is variable, up to $10 \mathrm{~mm}$. The siliceous body is generally opaque, and presents variable colours, described as reddish- brown(Moderate brown 5YR 3/4, Moderate Brown 5YR 4/4), bluish (Medium Bluish Gray 5B 5/1, Light Bluish Gray 5B 7/1), whites (Bluish White5B 9/1, Light Gray N6) and greys (Medium Bluish Gray 5B 5/1, Medium Light Gray N5 or Very Light Grey N7), distributed homogeneously but with frequents zone changes. It is sometimes possible to recognize some sedimentary structures as lamination, gypsum relicts or chickenwire anhydrite formations. Lutetian cherts are generally opaque; those sampled at the surface present a white patina, and frequent fissures.

Thin sections of these samples show, as diagnostic features, the presence of gypsum pseudomorphs and the absence of carbonates (confirmed also by the $\mu$-DRX), with a mudstone texture. Quartz is present as undulated microquartz (50\%) and length-slow chalcedony, lutecine (40\%). The rest is described as opaque minerals $(5 \%)$, ferric oxides $(3 \%)$ and gypsiferous relicts $(2 \%)$.

The component spectrum obtained by ESEM show a typical chemical composition (S, K, $\mathrm{Mg}, \mathrm{Al}$ ) of evaporite palaeoenvironment. (See Figure 6.).

\section{Bartonian cherts}

Bartonian cherts as supports present irregular angular or rounded morphologies, with decimetric to metric sizes. Carbonated cortical zones present also orange coloured (Dark Yellowish Orange 10YR 6/6, Grayish Orange 10YR 7/4) with 2-5mm width. The samples present greyish colour (Medium Bluish Gray 5B 5/1, Medium Light Gray N5 or Very Light 
Gray N7), are translucent, and without allochemical elements, that define a crystalline carbonated texture

Petrologic analysis shows as diagnostic features an abundant presence of carbonates and fibrous silica. Bartonian cherts are composed by fibrous silica, both length-slow chalcedony, as lutecine $(48 \%)$, and length-fast chalcedony (10\%) forms. Undulated microquartz $(36 \%)$ is also present, and the rest is formed of rhomboidal carbonates (3\%), mainly filling fissures, ferric oxides (2\%) and opaque minerals (1\%).

Micro XRD shows that they are composed of quartz, calcite and dolomite. (See Figure 7.) ESEM spectrum shows in some samples low proportion in sulphates. They are justified by the nearness of gypsiferous deposits to the sampled outcrop. This fact suggests the introduction of detritical gypsum in the basal zone of Bartonian Fm, and could cause the presence of length-slow chalcedony.

\section{Oligocene cherts}

This chert in primary position appears as lens-shaped layers and pebbles of decimetric size in stratified limestone. The material can present some greyish-brown patina. The cortex is calcareous, stratified, grey to black, not gradual and less than $1 \mathrm{~mm}$ thick. Its colour is blackish-green to light brown (Very dark grayish brown 2.5Y 3/2, Grayish brown 2.5Y 5/2) and has an opaque appearance, but near the cortex it may have brownish tonalities due to ferric oxidations. It is soft to the touch, and breaks with a conchoidal fracture and has very good knapping properties. Its sedimentary structure is laminated and the allochemical elements are ooids, pellets and bioclasts such as gastropods and spicules.

Petrological analysis shows an abundant presence of carbonates and microfossils (charophytes, spicules, algae, gastropods, foraminifera, and ooids) as diagnostic feature. The samples are formed of carbonates (40\%), bioclasts, and micritic calcite. Silica is present as undulant microquartz (30\%), cryptocristalline quartz (10\%) and biogenic opal from fossilized organism $(5 \%)$. Ferric oxides $(4 \%)$ and opaque minerals $(1 \%)$ are also present.

Micro-XRD demonstrate the presence of quartz, calcite and in this case also moganite. (See Figure 8.).

\section{Pliocene}

This chert appears mainly in secondary locations and is very heterogeneous due to the geological formation of origin: the Pliocene aged stratified deposits of conglomerates derive from the Triassic deposits of the Prelittoral range and the marine Palaeogene of the Ebro basin border (Gallart 1981). Therefore, this chert would have its origin in the Muschelkalk of the Prelittoral range or in the Valldeperes formation of the Ebro basin, latter being the most abundant source. The macroscopic similarities, and the microscopic features, supported this origin (Gómez de Soler 2009). In general, nodules are centimetric to decimetric. Sometimes white patina and clay concretions are present. Its calcareous neo-cortex, without transition, presents less than $1.5 \mathrm{~mm}$ of thickness. Its colour is very heterogeneous, and renages between bluish-grey and brownish-grey ranges (Bluish gray 5/1, Gray 10YR 6/1) generally translucent. With a fine to coarse texture, it breaks with a conchoidal fracture, in some cases with fissures that do not always allow for good knapping. Some oxides are observed and sedimentary structures do not seem to be present. Allochemical components are very scarce.

Thin sections show these cherts are microcrystalline with length-fast chalcedony. The samples are composed of microquartz (55\%), followed by a high percentage of megaquartz (30\%), and length-fast chalcedony (5\%). Ferric oxides (5\%), rhomboidal and micritic carbonates (3\%), and opaque minerals (2\%) are also present. (See Figure 9.). 
a)
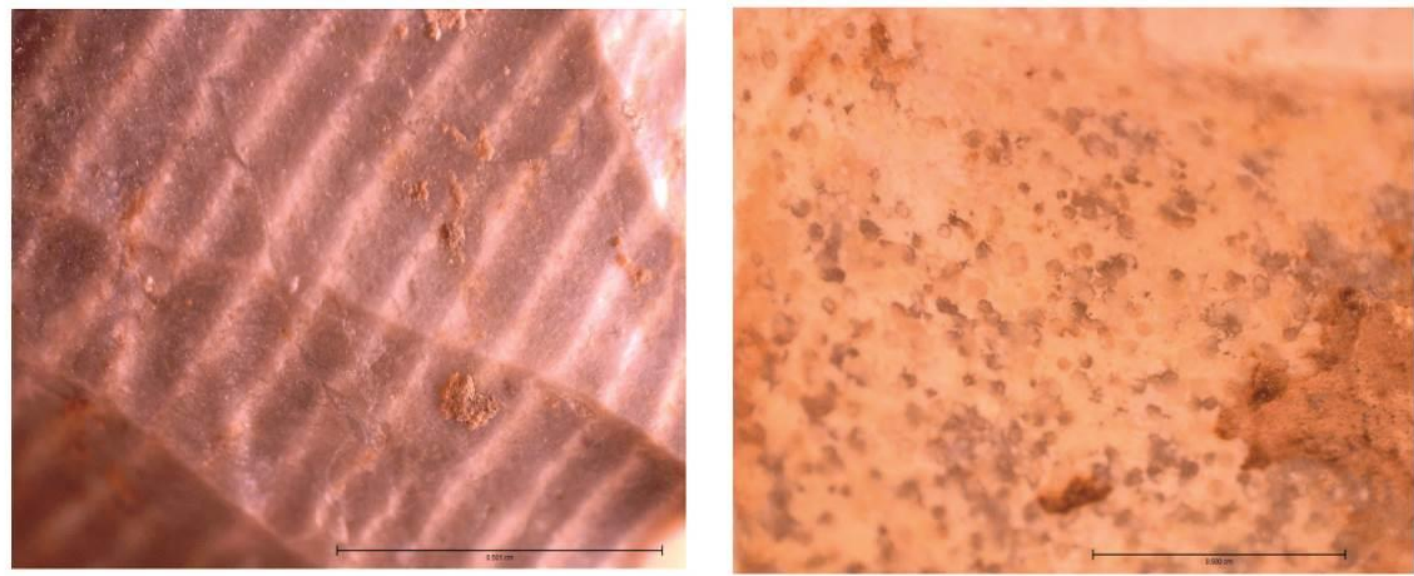

b)
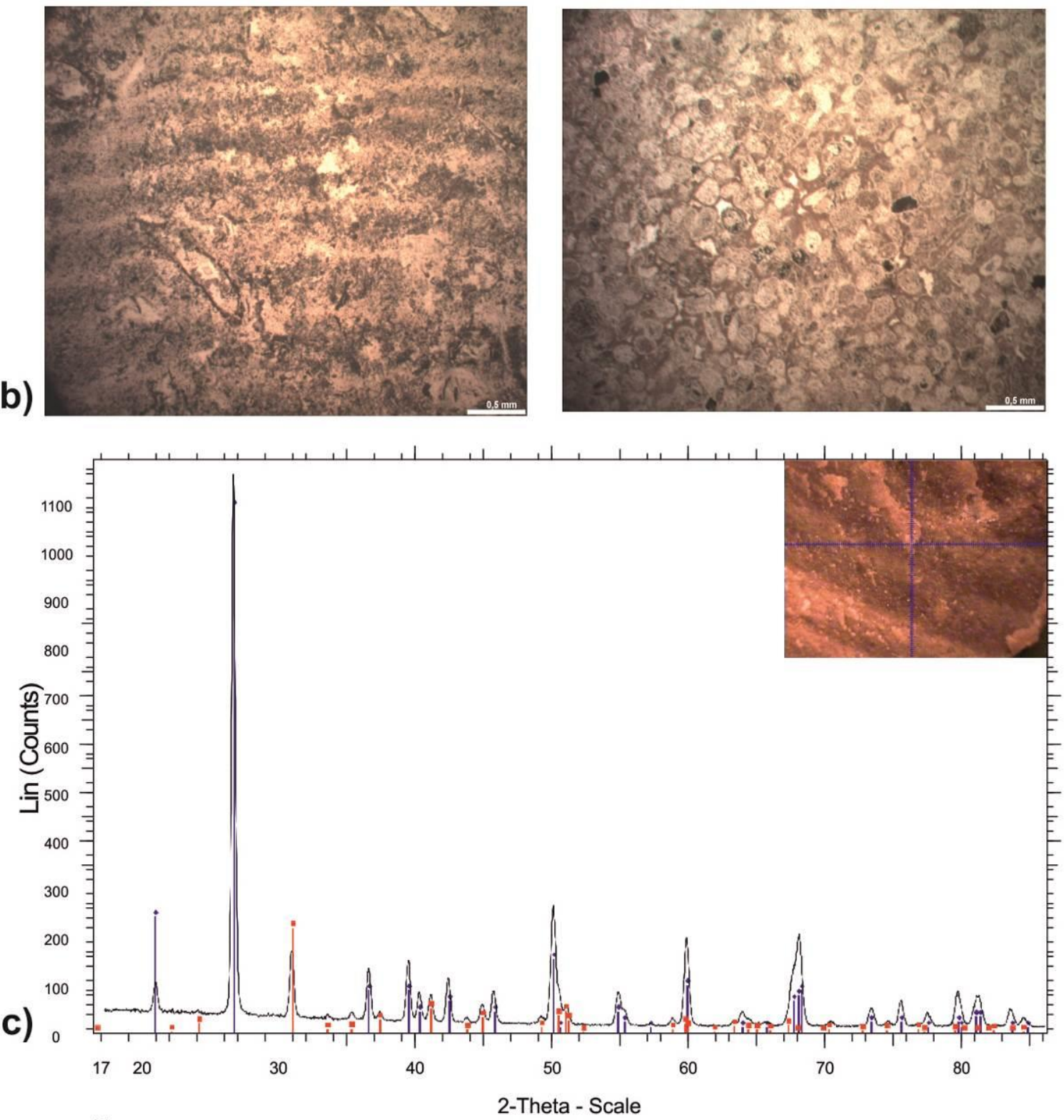

WLR_1 - File: d8_ari16040_p.raw - Temp: $25^{\circ} \mathrm{C}$ (Room) Do0-033-1161(D) - Quartz, syn - SiO2 2

Figure 4. a) Macroscopical appearance of Muschelkalk chert samples with Liesengang rings (left) and microfossils (right). b) Thin section images with plane polariser showing lamination because of different silicacarbonates content (left) and packstone texture (right). c) $\mu$-XRD of the indicated point. 
a)
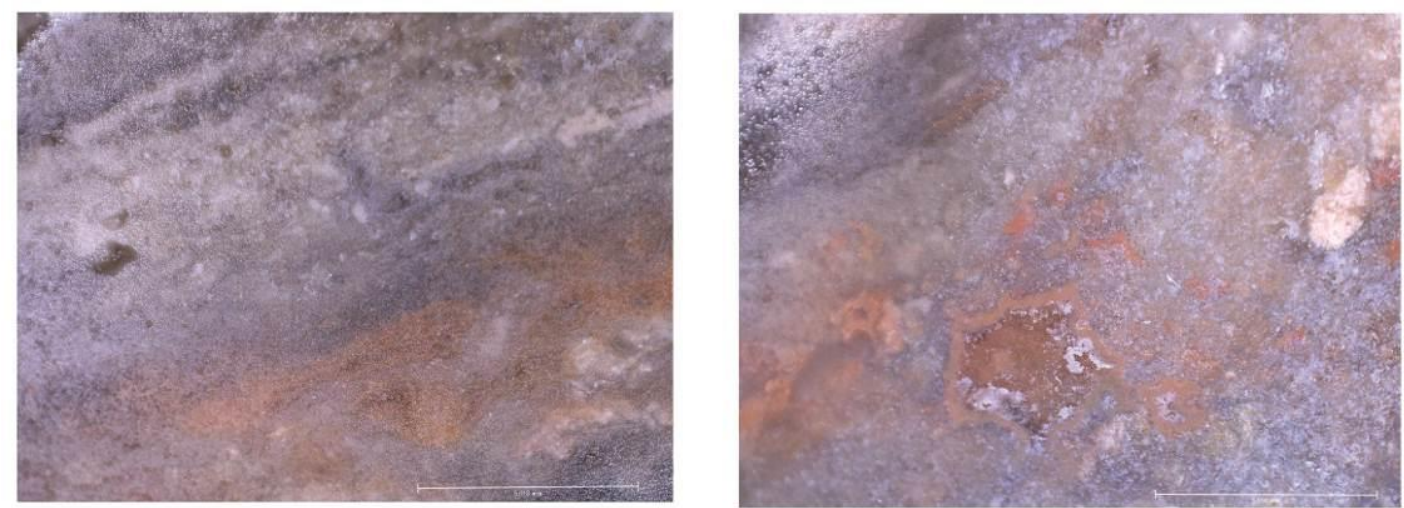

b)
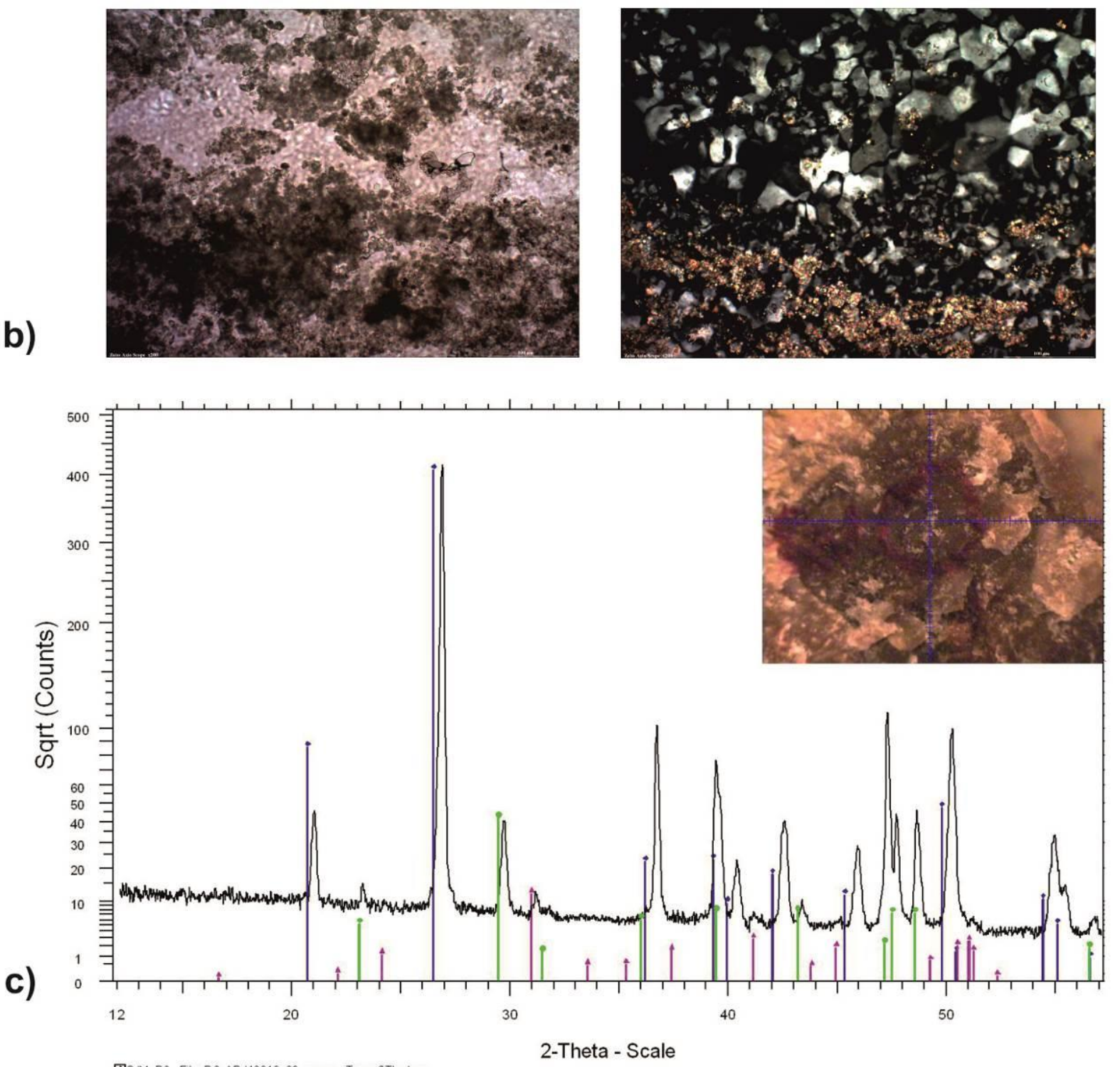

SSIM. P3 - File: D8_ARJ16018_00_m.raw - Type: 2Th a done

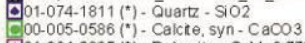

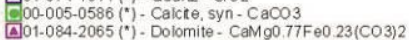

Figure 5. a) Macroscopic appearance of Thanetian cherts with lamination and presence of ferric oxides b) Thin section images (left: plane polariser) showing a high presence of carbonates and isometric microquartz and megaquartz (right:crossed polariser). c) $\mu$-XRD of the indicated point. 
a)
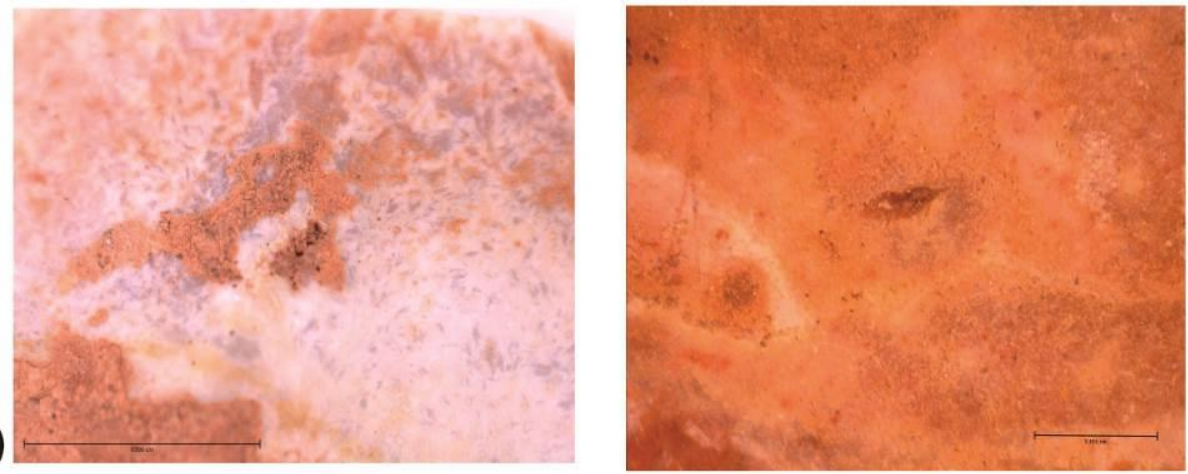

b)
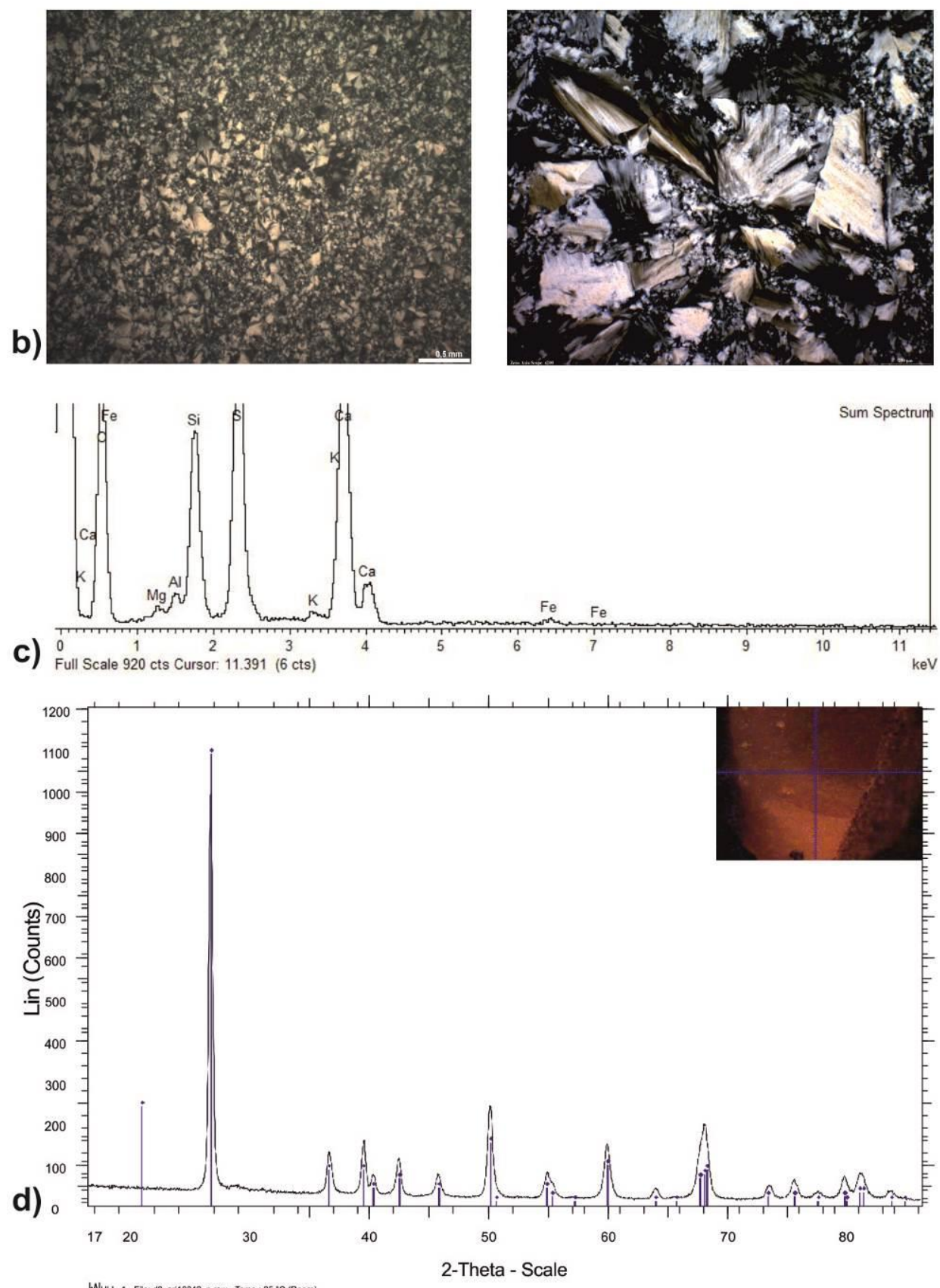

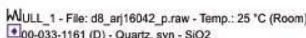

Figure 6. a) Stereoscopic microscope observations with evidences of gypsum relicts. b) Thin sections with crossed polariser showing microquartz (left) and length-slow chalcedony and a gypsum crystal (right). c) ESEM chemical component Spectrum. d) $\mu$-XRD of the indicated point. 
a)
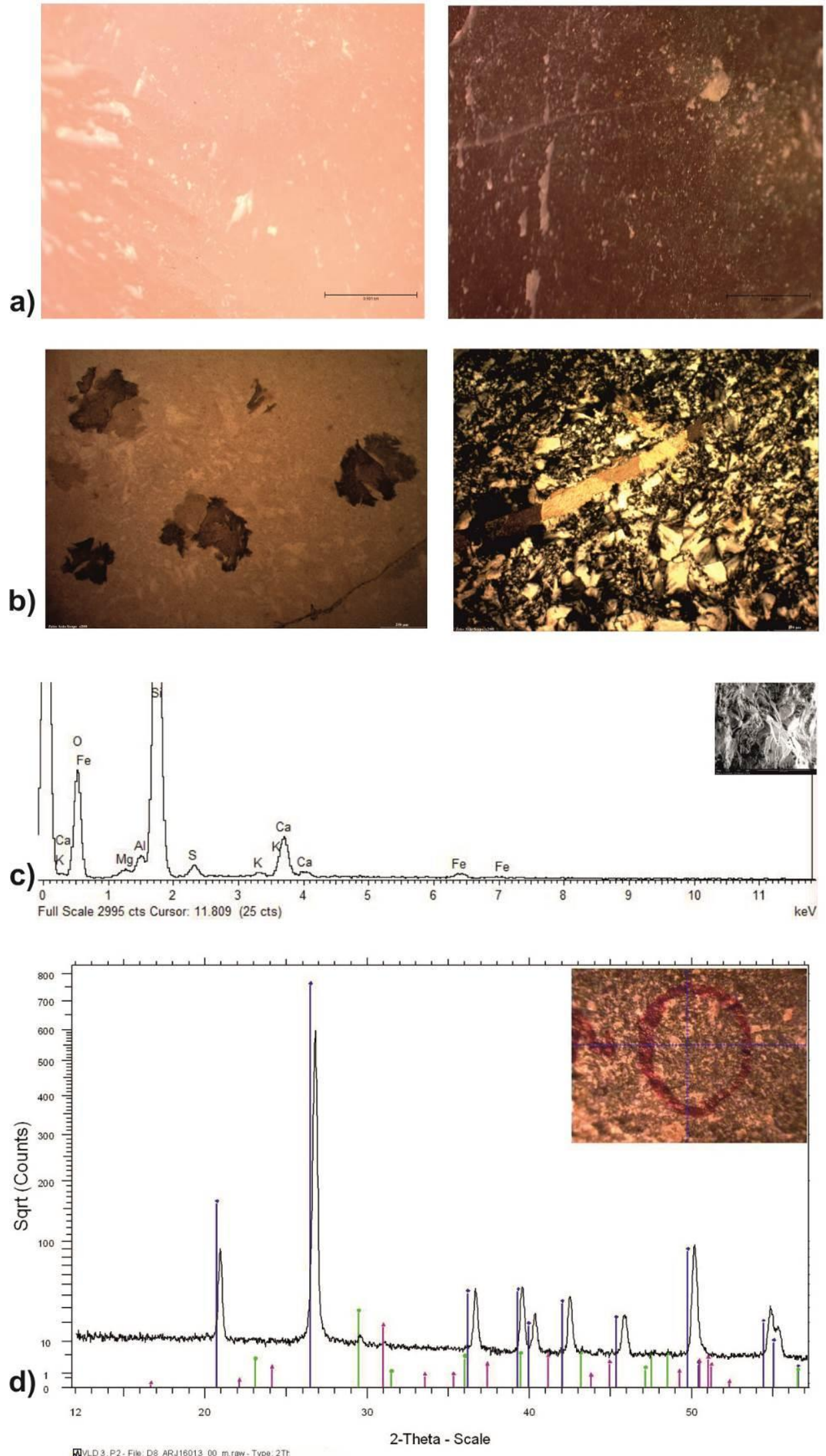

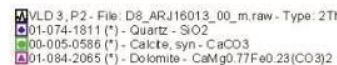

Figure 7. a) Macroscopic aspect of Bartonian cherts. b) Thin section with plane polariser showing carbonates crystals(left) and with crossed polariser showing length-fast chalcedony and carbonates filling fissures. c) ESEM chemical component Spectrum. d) $\mu$-XRD of the indicated point. 
a)
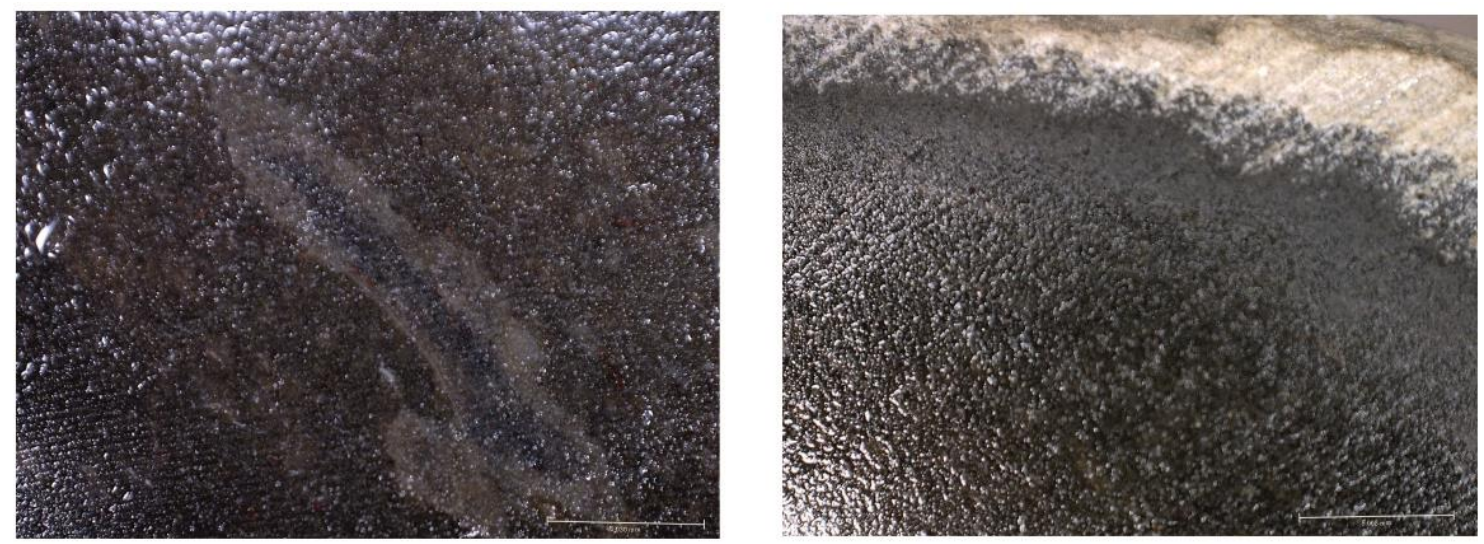

b)
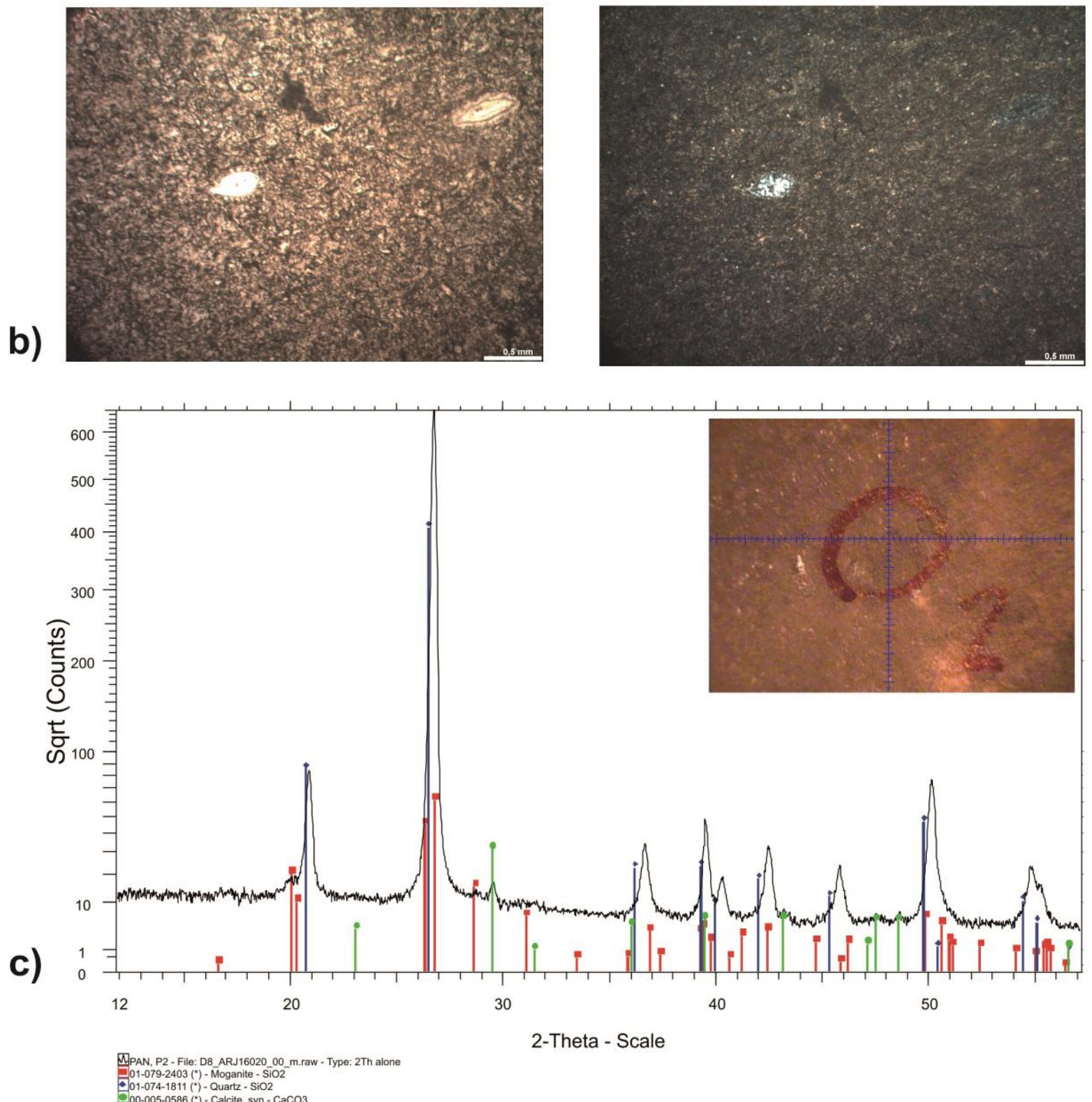

Figure 8. a) Macroscopic features of Oligocene cherts, with opaque appearance and calcareous cortex. b) Thin sections show a high percentage of carbonates, microquartz and replaced microfossils. c) $\mu$-XRD confirming the presence of silica (moganite \& quartz) and calcite. 
a)
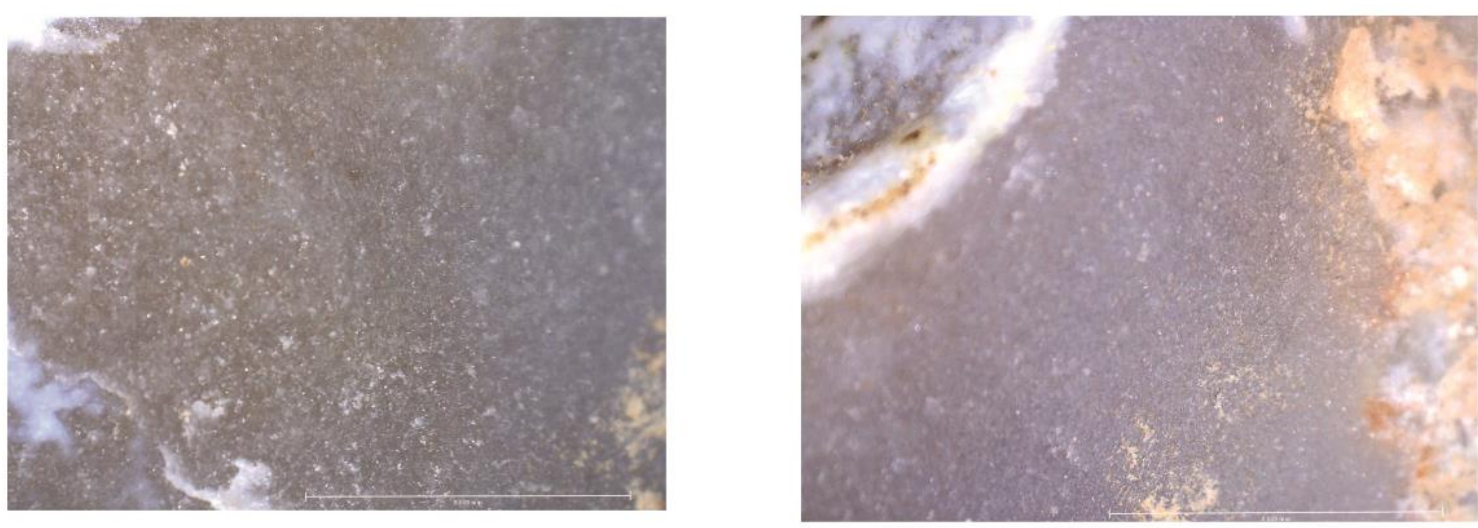

b)
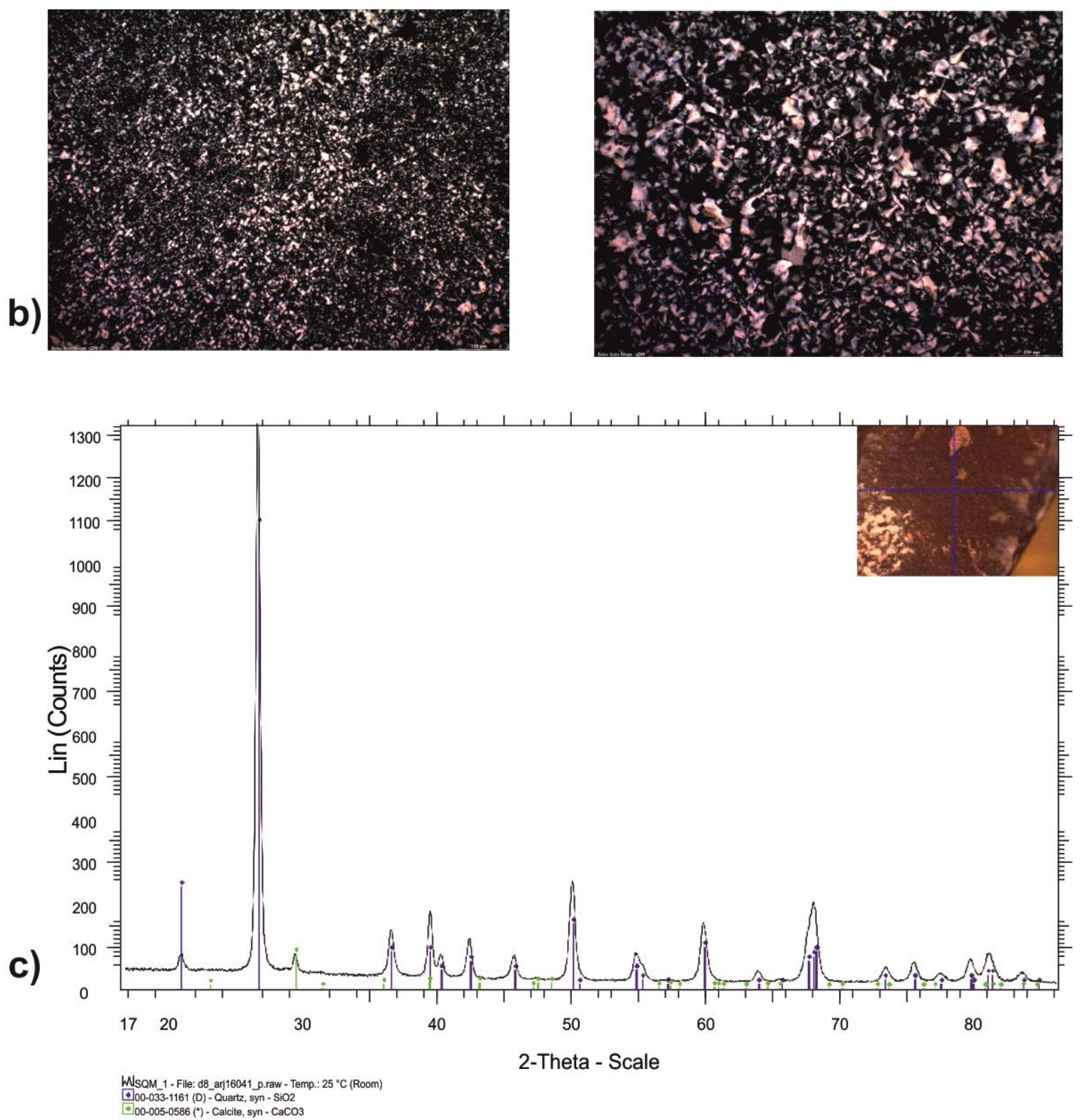

Figure 9. a) Macroscopic features of Pliocene cherts, with some white patina and translucent appearance. b) Thin sections show macroquartz, microquartz and length-fast chalcedony. c) $\mu$-XRD confirms the presence of quartz and calcite. 


\section{Discussion}

In a territory where siliceous resources and prehistoric occupations are abundant, prospecting for, and characterising chert are essential steps for understanding dynamics between hunters-gatherers groups and their mineral landscape.

As archaeologists, we are interested in establishing the geographical origin of lithic assemblages; chert despite its monotone composition (Malyk-Selivanova et al. 1998; Aubry et al. 2003) present a high degree of variability that makes it advisable to apply a multi-scale approach to its characterisation (Luedtke 1992; Turq 2005; Crandell 2006).

According to most of archaeopetrological studies, chert should be characterised though a combination of macro- and microscopic analysis. Discriminating characteristics established by these analysis (morphology, mean size, roughness, sedimentary structures, textural and mineralogical composition) must be contextualized with previous knowledge of outcrop deposition (Tricart \& Vonfelt 1955; Sittler \& Demangeon 1963) because the palaeoenvironmental conditions of the deposits from which it was formed determines chert's characteristics and chemical components (Whittle \& Alsharhan 1993; Murray 1994; Dasgupta et al. 1999; Umeda 2003; Becker \& Bechstädt 2006).

Other techniques used in characterisation, like DRX and ESEM are useful for distinguishing between the different mineralogical phases of silica and obtaining high resolution images of the surface and preliminary information as to its chemical composition (Monroe 1964; Froehlich 1974; Aubry 1975; Montoriol-Pou \& Clemente 1979; Gao \& Land 1991; Bustillo et al. 1998; Shackley 2008).

Our study reflects that macroscopic analyses are useful for establishing an initial distinction between chert enclosed in carbonated or evaporite rocks. Samples enclosed in calcareous lithologies show, as diagnostic features, the presence of laminated structures, Liesengang rings, abundant microfossils and frequent ferric oxides inclusions. Rocks with gypsiferous relicts, chicken-ware anhydrite pattern, and oxide inclusions are related to evaporite lithologies.

An analysis of the mineralogy, texture and impurity content, using thin sections observations, show that chert enclosed in carbonate rocks present a high presence of carbonates and microfossils, and microquartz and length-fast chalcedony (chalcedonite)predominate. Chert nodules located in evaporite sediments have, as microscopic features, fibrous silica, mainly length-slow chalcedony (quartzine and lutecite), and frequently contain gypsum pseudomorphs, while carbonates are absent.

Some samples associated with the basal zone of the carbonated sequences (Bartonian), contained the other type of fibrous silica, length-slow chalcedony, typical of sulphate environments (Folk \& Pittman 1971). This fact suggests that those samples are possible breccias, which had their origins in the erosion of Lutetian deposits and were resedimented in marls lithologies, if we consider the relationship described above between forms of silica and depositional environments. This relationship confirms that length-slow chalcedony is always a testimony of evaporite sediments replacement and length-fast chalcedony is commonly evidence of calcareous replacement, or -in gypsiferous chert- as a product of $\mathrm{pH}$ or $\mathrm{CO}_{3}$ content change (Cayeux 1929; Millot 1960; Bustillo 1976; Arbey 1980).

The $\mu$-XRD and ESEM analysis confirmed and improved the results from stereoscopic and petrographic microscope observations. This makes it easier to link the outcrops with one rather than another (Muschelkalk vs Eocene formations). In the case of cryptocrystalline chert, ESEM is a useful tool for determining textures.

It should be noted that multi-scalar analysis, based on an intensive programme of prospecting, the study of sedimentary models and macro- and microscopic analysis of silicifications is the correct procedure for obtaining a series of characterisation. Interrelating 
these patterns assists in defining regional catchment dynamics (Mauger 1985; Mangado 2000; Fernandes et al. 2006; Tarriño 2006; Fernandes 2007 ; Shackley 2008; Bustillo et al. 2009; Fernandes 2012).

\section{Conclusions}

In areas where archaeological sites and silicifications are abundant, intensive prospecting programmes are a fundamental work-tool to acquire the necessary knowledge about the territory and its raw material catchment possibilities.

Characterising outcrops and cherts makes it possible to establish the provenance of archaeological lithic assemblages.

Petrographic features of chert as mainly defined by the macroscopic, thin sections, and DRX analysis performed, are coherent with the data on the outcrops' different palaeoenvironments.

Silicifications originated from sedimentary models ranging from marine depositions (Triassic), through continental sediments (Thanetian), hypersaline lakes or sabkha (Lutetian), to shallow palustrines and very extensive lacustrine zones (Bartonian), and finally, to endorheic lacustrine and alluvial deposition (Sannonian \& Stampian).

Carbonates, microfossils and microquartz predominate in the Triassic samples. Intercalated carbonates and macroquartz lamination are characteristic of Thanetian chert. Fibrous quartz is the main component of Lutetian and Bartonian samples. Oligocene samples have a higher microquartz, microfossil and carbonate content., Chert formed in calcareous environments generally has a high carbonates content, and the evaporite cherts contain gypsum relicts and pseudomorphs.

The premise that found length-fast chalcedony is found in calcareous conditions and length-slow in evaporite conditions, is a feature that would be useful in diagnosis but could not be assessed in some of our samples. We suggest that it is possible that most of the chert located in the basal zone of the carbonated sequences (Bartonian), is breccial in origin, being a product of the erosion of their lower levels (Lutetian) that was followed by resedimentarion, which could explain why we find both forms of fibrous silica in it.

\section{Acknowledgements}

Research and authors receive support from Projects CGL2012-38358, CGL2012-38434C03-03 and SGR2009-324 from MINECO of Spain and AGAUR of Generalitat de Catalunya. Soto, M. has a Research Grant FI-DGR2013 from AGAUR of Generalitat de Catalunya.

\section{References}

Anadón, P. 1978, El Paleógeno inferior anterior a la trasgresión "biarritziense" (Eoceno medio) entre los ríos Gaià y Ripoll (Provincias de Tarragona y Barcelona). Estudios Geológicos, 34: 431-440. (in Spanish) ("Lower Palaeogene before the "biarritziense" transgression (Middle Eocene) between Gaià and Ripoll rivers (Tarragona and Barcelona Provinces)")

Anadón, P., Cabrera, L., Colldeforns, B. \& Sáez, A. 1989, Los sistemas lacustres del Eoceno superior y Oligoceno del sector oriental de la Cuenca del Ebro. Acta Geológica Hispánica, 24: 205-230. (in Spanish) ("Lacustrine systems of Upper Eocene and Oligocene in the Eastern sector of the Ebro Basin")

Anadón, P. \& Marzo, M. 1986, Sistemas deposicionales eocenos del margen oriental de la Cuenca del Ebro: Sector Igualada-Montsant. In: XI Congreso Español de 
Sedimentología. Guía de la excursiones. (Anadón, P. \& Cabrera, L., Eds.), Generalitat de Catalunya.Comissió Interdepartamental de Recerca i Innovació Tecnológica. CIRIT, Barcelona: p. 4.1-4.59. (in Spanish) ("Eocene depositional systems of the oriental margin of the Ebro Basin: Igualada-Montsant sector")

URL: http://www.raco.cat/index.php/ActaGeologica/article/view/75356

Arbey, F. 1980, Les formes de la silice et l'identification des evaporites dans les formations silicifiees. Bulletin des Centres de Recherches Exploration-Production Elf-Aquitaine, 4(1): 309-365. (in French) ("Silica forms and evaporites identification in silicified formations")

Aubry, M.P. 1975, Recherches sur la nannopetrographie des roches siliceuses. Bulletin trimestriel de la Société Géologique de Normandie et des amis du Muséum du Havre, 62(2): 9-50. (in French) ("Researches about the nano petrography of siliceous rocks")

Aubry, T., Chauvière, F.-X., Mangado LLach, X. \& Sampaio, J.D. 2003, Constitution, Territoires d'approvisionnement et fonction des sites du Paleolithique Superieur de la Basse Vallée du Coâ (Portugal). In: Perceived Landscapes and Built Environments. The cultural geography of Late Palaeolithic Eurasia (Vasil'ev, S.A., Soffer, O. \& Kowlozski, W., Eds.) BAR international Series Vol. S1122, Archeopress, Liège: p. 8392. (in French) ("Setting up, catchment territories and functionalities of Upper Palaeolithic sites from Lower Coa Valley (Portugal)")

Becker, F. \& Bechstädt, T. 2006, Sequence stratigraphy of a carbonate-evaporite succession (Zechstein 1, Hessian Basin, Germany). Sedimentology, 53: 1083-1120. doi:10.1111/j.1365-3091.2006.00803.x

Bignot, G. 1988, Los microfósiles. Paraninfo, Madrid, 284 p. (in Spanish) ("Microfossils")

Binford, L.R. 1982, The Archaeology of place. Journal of Anthropological Research, 1(1): 531.

Bofarull, J. 1997, Estudi d'un teconcomplexe del Paleolitic Mitjà. La industria del nivell E de l'Abric Romani (Capellades, Anoia). Licenciatura thesis at Universitat Rovira i Virgili, Tarragona, 114 p. (in Catalonian) ("Study of a Middle Technocomplex. The industry of Level E of the Abric Romaní (Capellades, Anoia)")

Boggs, J., S. 2009, Petrology of sedimentary rocks (2nd ed.). Cambridge University Press, Cambridge, $600 \mathrm{p}$.

Bressy, C. 2003, Caracterisation et gestion du silex des sites Mésolithiques et Néolithiques du nord-ouest de l'arc alpin. Un aproche pétrographique at géochimique. BAR International Series Vol. 1114. Archaeopress, Oxford, 243 p. (in French) ("Characterisation and chert management of Mesolithic and Neolithic sites from the Northwest Alpine region")

Bustillo, M.A. 1976, Texturas de rocas silíceas inorgánicas en ambiente continental y significado genético. Estudios geológicos, 32: 371-383. (in Spanish) ("Inorganic siliceous rocks textures in continental environments and its genetical meaning")

Bustillo, M.A. 1982, Minerales de la sílice en ambiente sedimentario: estudio y aplicaciones. Expominer, 82: 27-34. (in Spanish) ("Silica minerals in sedimentary environments:study and applications")

Bustillo, M.A. 2010, Silification of continental carbonates. In: Carbonates in continental settings: geochemistry, diagenesis and applications (Alonso-Zarza, A.M. \& Tanner, L.H., Eds.) Developments in sedimentology Vol. 62, Elsevier, Oxford: p. 153-182. 
Bustillo, M.A., Castañeda, N., Capote, M., Consuegra, S., Criado, C., Díaz-del-Río, P., Orozco, T., Pérez-Jiménez, J.L. \& Terrades, X. 2009, Is the macroscopic classification of flint useful? A petroarchaeological analysis and characterization of flint raw materials from the Iberian Neolithic mine of Casa Montero. Archeometry, 51(2): 175196. doi:10.1111/j.1475-4754.2008.00403.x

Bustillo, M.A., Delgado, A., Rey, J. \& P.A., R.-O. 1998, Meteoric water participation in the genesis of Jurassic cherts in the Subbetic of southern Spain - a significant indicator of penecontemporaneous emergence. Sedimentary Geology, 119: 85-102. doi:10.1016/S0037-0738(98)00050-5

Carbonell, E., (Ed), 2012, Time and Space In Level J of Abric Romaní (Capellades, Spain), Vertebrate Paleobiology and Paleoanthropology Book Series. Springer, Dordrecht, 411 p.

Carbonell, E., Mosquera, M., Ollé, A., Rodríguez, X.P., Sala, R., Vaquero, M. \& Vergès, J.M. 1992, New elements of the Logical Analytic System. First International Meeting on Technical Systems to Configure Lithic Objects of Scare Elaboration. Chaier Noir Vol. 6. Reial Societat Arqueològica Tarraconense, Tarragona, $61 \mathrm{p}$.

Cayeux, L. 1929, Les roches sedimentaires de France. Roches siliceuses. Mémoire Carte Geologique. Imprimerie Nationale, Paris, 774 p. (in French) ("Sedimentary rocks from France. Siliceous rocks")

Colldeforns, B., Anadón, P. \& Cabrera, L. 1994, Nuevos datos sobre la litoestratigrafía del Eoceno inferior de la zona suroriental de la Cuenca del Ebro (Sector Pontils-Montblanc, provincias de Tarragona y Barcelona). Geogaceta, 16: 1-6. (in Spanish) ("New data about the lithostratigraphy of Lower Eocene from the sotuheastern zone of the Ebro Basin (Pontils-Montblanc Sector, Tarragona and Barcelona Provinces)")

Colombo, F. 1986, Estratigrafía y sedimentología del Paleógeno continental del borde meridional occidental de los catalánides (Provincia de Tarragona, España). Cuadernos de Geología Ibérica, 10: 55-115. (in Spanish) ("Stratigraphy and sedimentology of the continental Paleogene from Western meridional edge of the Catalanides (Tarragona Province, Spain)")

URL: http://revistas.ucm.es/index.php/CGIB/article/view/CGIB8686110055A/2722

Colombo, F. \& Escarrè, V. 1994, Arquitectura deposicional y sedimentología del Complejo de Ulldemolins (Paleógeno) Tarragona. Geogaceta, 15: 37-40. (in Spanish) ("Depositional architecture and sedimentology from the Ulldemolins Complex (Palaeogene) Tarragona")

Colombo, F. \& Vergés, J. 1992, Geometria del margen S.E. de la Cuenca del Ebro: discordancias progresivas en el Grupo Scala Dei. Serra de La Llena. (Tarragona). Acta Geologica Hispanica. Special issue: Homenaje a Oriol Riba Arderiu, 27(1-2): 33-53. (in Spanish) ("Geometry from Southeastern margin of the Ebro Basin: progressive discordances from Scala Dei Group. Serra de la Llena (Tarragona)")

Crandell, O.N. 2006, Macroscopic and microscopic analysis of chert. A proposal for standarisation of methodology and terminology. Buletinul Cercurilor Stiintifice Studentesti, Arheologie - Istorie - Muzeologie, 12: 7-30.

Dasgupta, H.C., Sambasiva Rao, V.V. \& Krishna, C. 1999, Chemical environments of deposition of ancient iron- and manganese-rich sediments and cherts. Sedimentary Geology, 125: 83-98. doi:10.1016/S0037-0738(98)00148-1 
Demars, P.Y. 1982, L'utilisation du silex au Paléolithique Supérieur: choix, aprovisionnement, circulation. L'exemple du Bassin de Brive. Vol. 5. Cahiers du Quaternaire. Centre national de la recherche scientifique, Paris, 256 p. (in French) ("Chert usage during Upper Palaeolithic:choice, catchment, circulation. The Brive Basin example")

Doce, R. \& Alcobé, X. 1997, Crystallinity index of some cherts from Ulldemolins complex and Montblanc Formation (Tarragona, Spain). In: Siliceous Rocks and Culture (Ramos, A. \& Bustillo, M.A., Eds.) Monográfica arte y arqueología Vol. 42, Universidad de Granada, Granada: p. 111-116.

Féblot-Augustins, J. 1999, La mobilité des groupes paléolithiques. Bulletins et Mémoires de la Societé d'anthropologie de Paris, Nouvelle Série, 11(3-4): 219-260. (in French) ("The mobility of Palaeolithic Groups")

URL: http://www.persee.fr/web/revues/home/prescript/article/bmsap_00378984_1999_num_11_3_2551

Fernandes, P. 2012, Itinéraires et transformations du silex: une pétroarchéologie refondée, application au Paléolithique moyen. Ph.D. thesis at the École doctorale Sciences et Environnement, L'Université de Bordeaux I, Bordeaux, 623 p. (in French) ("Itineraries and transformations of chert: a renovated petroarchaeology. Application to the Middle Palaeolithic") URL: http://www.theses.fr/2012BOR14533

Fernandes, P., Delvigne, V., Affolter, J., Piboule, M., Raynal, J.-P., Séronie-Vivien, M.-R., Dousse, M. \& Tufféry, C. 2010, Project Collectif de Recherche rapport d'activité 2010. PCR Réseau de Lithothèques en Rhône-Alpes, Lyon, 228 p. (in French) ("Collective Research Project. 2010 Activities Report.")

Fernandes, P., Le Bourdonnec, F.X., Raynal, J.P., Poupeau, G., Piboule, M., Moncel, M.H. 2007 Origins of prehistoric flints: The neocortex memory revealed by scanning electron microscopy. Comptes Rendus Palevol, 6: 557-568. doi:10.1016/j.crpv.2007.09.015

Fernandes, P., Raynal, J.P. \& Moncel, M.H. 2006, L'espace minéral au Paléolithique moyen dans le Sud du Massif central : premiers résultats pétroarchéologiques. Comptes Rendus Palevol, 5: 981-993. (in French) ("The mineral space during Middle Palaeolithic in the Southern Central Massif: first petroarchaeologist results") doi:10.1016/j.crpv.2007.09.015

Flörke, O., Köhler-Herbertz, B., Langer, K. \& Tönges, I. 1982, Water in microcristalline quartz of volcanic origin: agates. Contribution to Mineralogy and Petrology, 80: 324333.

Folk, R.L. 1974, Petrology of Sedimentary Rocks. Hemphill Publishing Company, Austin, Texas, $182 \mathrm{p}$.

Folk, R.L. \& Pittman, J.S. 1971, Length-slow chalcedony; a new testament for vanished evaporites. Journal of Sedimentary Research, 41(4): 1045-1058. doi:10.1306/74D723F1-2B21-11D7-8648000102C1865D

Folk, R.L., Weaver, C.E 1952, A study of texture and composition of chert. American Journal of Science, 250: 498-510. doi:10.2475/ajs.250.7.498

Froehlich, F. 1974, Nature, importance relative et place dans la diagenèse des phases de silice présentes dans les silifications de craies du Bassin océanique de Madagascar (Ócean Indien) et du Bassin de Paris. Bulletin de la Société Géologique de France (Series 7), 16(5): 498-508. (in French) ("Nature, relative importance and diagenetic phases 
presented in silicified chalks from Oceanic Basin of Madagascar (Indian Ocean)") doi: 10.2113/gssgfbull.S7-XVI.5.498

Gallart, F. 1981, Neógeno superior y cuaternario del Penedès (Catalunya, España). Acta Geológica Hispánica, 16: 151-156. (in Spanish) ("Upper Neogene and Quaternary from the Penedès (Catalunya, Spain)")

Gao, G. \& Land, L.S. 1991, Nodular chert from the Arbuckle Group, Slick Hills, SW Oklahoma: a combined field, petrographic and isotopic study. Sedimentology, 38: 857870. doi:10.1111/j.1365-3091.1991.tb01876.x

García-Antón, D. 2010, Methodological Approach to the Selection of Palaeolithic Raw Material in Supply Areas Located in Secondary Deposits. Human Evolution, 25 (1-2): $1-18$.

Geneste, J.M. 1992, L'approvisionnement en matières premières dans les systemes de production lithque: la dimension spatiale de la technologie. In: Tecnología y Cadenas Operativas Líticas: Reunión Internacional, 15-18 Enero de 1991 (Mora, R., Terradas, X., Parpal, A. \& Plana, C., Eds.) Treballs d’Arqueología Vol. 1, Departament d'Història de les Societats Pre-capitalistes i d'Antropologia Social de la Universitat Autònoma de Barcelona, Bellaterra: p. 1-36. (in French) ("Raw matrials catchment in lithic productions systems: the saptial dimension of technology")

URL: http://www.raco.cat/index.php/TreballsArqueologia/article/view/50042

Gómez de Soler, B. 2007, Áreas de captación y estrategias de aprovisionamiento de rocas silíceas en el nivel L del Abric Romaní (Capellades, Barcelona). llicenciatura thesis at Rovira i Virgili, Tarragona, 215 p. (in Spanish) ("Catchment areas and provisioning strategies os siliceous rocks in the Level L of the Abric Romani (Capellades, Barcelona)")

Gómez de Soler, B. 2009, Àrees de captació, tecnologia lítica i estràtegies d'aprovisionament de roques silicies en el nivell L de l'Abric Romaní(Capellades, Barcelona). Quadern de Prehistòria Catalana, 17: 11-56. (in Catalonian) ("Catchment areas, lithic technology and provisioning strategies of siliceous rocks in the Level L of the Abric Romaní (Capellades, Barcelona)")

Grégoire, S. 2001, Apports et limites des nouvelles techniques de la pétroarchéologie préhistorique. Comptes Rendus de l'Académie des Sciences Paris, 332: 479-382. (in French) ("Contributions and limits of new prehistorical petroarchaeologist techniques")

Heaney, P.J. 1995, Moganite as an indicator for Vanished Evaporites: a testament reborn? Journal of Sedimentary Research, 65(A): 633-638. doi:10.1306/D4268180-2B26-11D7$\underline{648000102 \mathrm{C} 1865 \mathrm{D}}$

Luedtke, B.E. 1992, An archaeologist's guide to chert and flint. Archaeological Research Tools Vol. 7. Institute of Archaeology, University of California, Los Angeles, 172 p.

Malyk-Selivanova, N., Ashley, G.M., Gal, R., Glascock, M.D. \& Neff, H. 1998, GeologicalGeochemical Approach to "Sourcing" of Prehistoric Chert Artifacts, Northwestern Alaska. Geoarchaeology: An International Journal, 13(7): 673-708. doi:10.1002/(SICI)1520-6548(199810)13:7<673::AID-GEA2>3.0.CO;2-3

Mangado, J. 2006, El aprovisionamiento en materias primas líticas: hacia una caracterización paleocultural de los comportamientos paleoeconómicos. Trabajos de prehistoria., 63(2): 79-91. (in Spanish) ("Lithic raw materials provisioning: towards a palaeocultural characterisation of the palaeoeconomic behaviour") doi:10.33989/tp.2006.v63.i2.18 
Mangado, X. 2000, La caracterización y el aprovisionamiento de los recursos abióticos en la Prehistoria de Cataluña: las materias primas silíceas del Paleolítico superior final y el Epipaleolitico. Ph.D. thesis at the Departamento de Prehistoria, Historia Antigua y Arqueología, Universidad de Barcelona, Barcelona, 425 p. (in spanish) ("The characterisation and the abiotic resources provisioning during the Prehistory in Catalonia: the siliceous raw materials of the Final Upper Palaeolithic and Epipalaeolithic")

Marzo, M. \& Calvet, F. 1985, Guía de la excursión: Triásico de los Catalánides. II Coloquio de Estratigrafía y Paleogeografía del Pérmico y Triásico de España. Seccio de Ciencias Naturales, IEI; GEM, Barcelona, 175 p. (in Spanish) ("Trip Guide: the Triassic from the Catalanides")

Masson, A. 1979, Recherches sur la provenance des silex prehistoriques. Études prehistoriques, 15: 29-40. (in French) ("Researches about the prehistoric chert sourcing")

Mauger, M. 1985, Les materiaux siliceux utilises au Paleolithiques superieur en Ile de France. Occupation du territoire, deplacements et approche du mouvements saisonniers Th. 3e cycle thesis at the Archéologie préhistorique, Université de Paris I, Paris, 309 p. (in French) ("Siliceous raw materials used during Upper Palaeolithic in the Ile de France. Territorial occupation, displacements and approaches to the seasonal movements")

Millot, G. 1960, Silice, silex, silifications et croissance des cristaux. Bulletin du Service de la Carte Géologique d'Alsace et de Lorraine, 13(4): 129-146. (in French) ("Silica, chert, silicifications and crystals growth")

Monroe, E.A. 1964, Electron Optical Observations of Fine-Grained Silica Minerals. The American Mineralogist, 49: 339-347.

Montoriol-Pou, J. \& Clemente, I. 1979, Contribución al conocimiento del yacimiento de yeso de Vilaverd (Tarragona). Acta Geologica Hispanica. Special issue: Homenatge a LLuis Solé i Sabaris, 14: 125-128. (in Spanish) ("Contribution to the knowledge of Vilaverd Gypsum site (Tarragona)")

Morant, N. 1998, Estudi de les matèries primeres litiques del nivell I del jaciment de l'abric Romaní (Capellades, Barcelona). Licenciatura thesis at the Departament d'Història i Geografia, Universitat Rovira i Virgili, Tarragona, 240 p. (in Catalonian) ("Lithic raw materials from the Level I of the Abric Romaní, Capellades, Barcelona")

Murray, R.W. 1994, Chemical criteria to identify the depositional environment of chert: general principles and applications. Sedimentary Geology, 90: 213-232. doi: $\underline{10.1016 / 0037-0738(94) 90039-6}$

Ortí, F. 1989, Evaporitas marinas. In: Sedimentología Vol. 2 (Arche, A., Ed.), Consejo Superior de Investigaciones Científicas, Madrid: p. 89-178. (in Spanish) ("Marine evaporites")

Ortí, F. 1990, Las formaciones evaporíticas del Terciario continental de la zona de contacto entre la Cuenca del Ebro y los Catalánides. In: ormaciones evaporíticas de la Cuneca del Ebro y cadenas periféricas, y de la zona de Levante: Nuevas aportaciones y guía de superficie. (Ortí, F. \& Salvany, J.M., Eds.), Enresa-Universidad de Barcelona, Barcelona: p. 70-75. (in Spanish) ("Evaporites formations of the continental Tertiary of the Ebro Basin and the Catalanides contact zone") 
Ortí, F., L., R., Inglès, M. \& Playà, E. 2007, Depositional models of lacustrine evaporites in the SE margin of the Ebro Basin (Paleogene, NE Spain). Geologica Acta, 5(1): 19-34. URL: http://www.raco.cat/index.php/GeologicaActa/article/view/82346/107528

Ortí, F., Rosell, L., Playà, E., Salvany, J. M. 2012, Meganodular anhydritization: a new mechanism of gypsum to anhydrite conversion (Palaeogene-Neogene, Ebro Basin, North-east Spain). Sedimentology, 59(4): 1257-1277. doi:10.1111/j.13653091.2011.01305.x

Schmalz, R.F. 1960, Flint and Patination of Flint Artifacts. The Prehistoric Society, 26: 44-49.

Shackley, M.S. 2008, Archaeological petrology and the Archaeometry of Lithic Materials. Archeometry, 50(2): 194-215. doi:10.1111/j.1475-4754.2008.00390.x

Sittler, C. \& Demangeon, P. 1963, Les minéraux argileux, indicateurs de faciès, dans le Paléogène Languedocien. Bulletin du Service de la Carte Géologique d'Alsace et de Lorraine, 16(4): 213-226. (in French) ("Clay minerals, a facies indicator during the Palaeogene in the Languedoc")

Sopeña, A., Virgili, C., Arche, A., Ramos, A. \& Hernando, S. 1983, El Triásico. In: Geología de España Vol. 2 (Ríos García, J.M., Ed.), Instituto Geológico y Minero de España, Madrid: p. 47-63. (in Spanish) ("The Triassic")

Soto, M. 2010, Áreas de captación y modelos de aprovisionamiento de materiales abióticos en el Molí del Salt (Vimbodí, Tarragona). Màster thesis at Universitat Rovira i Virgili, IPHES-URV, Tarragona, 199 p. (in Spanish) ("Catchment areas and provisioning models of the abiotic materials of the Molí del Salt site")

Soto, M., Gómez de Soler, B., Vallverdú, J. \& Vaquero, M. 2011, El territori d'aprovisionament del sílex dels caçadors-recol·lectors del Molí del Salt (Vimbodí i Poblet). Aplec de Treballs, 29: 31-52. (in Catalonian) ("The chert sourcing territory of the Hunter-gatherer of the Molí del Salt site (Vimbodí i Poblet")

URL: http://www.raco.cat/index.php/Aplec/article/viewFile/245352/342723

Tarriño, A. 2006, El sílex en la Cuenca Vasco-Cantábricay Pirineo navarro. Caracterización y su aprovechamiento en la prehistoria. Monografías, 21. Museo nacional y centro de investigación de Altamira, Altamira, 263 p. (in Spanish) ("Chert from Vasco-Cantabrian Basin and Navarrean Pyrenees")

Tarriño, A. \& Ullibarri, M.A. 1992, La ficha como instrumento de inventario, análisis y comparación entre materiales silícieos pertenecientes a yacimientos arqueológicos y afloramientos naturales. In: Actas de la $2^{a}$ Reunión Nacional de Geoarqueología (Jordà, J.F., Ed.), Instituto Tecnológico Geominero de España y Asociación Española para el Estudio del Cuaternario, Madrid: p. 265-272. (in Spanish) ("The record file as an inventory, analytic and comparative instrument between siliceous materials from archaeological sites and natural outcrops")

Terradas, X. 2001, La gestión de los recursos minerales en las sociedades cazadorasrecolectoras. Vol. 4. Treballs d'etnoarqueologia. Consejo Superior de Investigaciones Científicas, Madrid, 177 p. (in Spanish) ("Mineral reosurces management in huntergatherer societies")

Terradas, X., Àlvarez, A., Bartrolí, R., Borrell, F., Clop, X., J.M., F., Garcia-Anton, M.D., Gibaja, J.F., Gómez, B., Grégoire, S., Mangado, X., Maroto, J., Martzluff, M., Molist, M., Ortega, D., Palomo, A., Sala, R., Soler, N. \& Vila, A. 2006, Estudio de la disponibilidad de rocas silíceas para la producción de instrumental lítico en la 
Prehistoria. In: Sociedades prehistóricas, recursos abióticos y territorio : actas de la III Reunión de trabajo sobre aprovisionamiento de recursos abióticos en la prehistoria, Fundación Ibn al-Jatib de Estudios de Cooperación Cultural, Barcelona: p. 63-72. (in Spanish) ("Siliceous rocks availability for the production of lithic instruments during Prehistory") URL: http://hdl.handle.net/10261/31249

Terrades, X. \& Molist, M. 2002, Dossier. Les restes lítiques en contextes arqueològics: estudis, interpretació i aplicacions. Cota Zero, 17: 9-11. (in Catalonian) ("Report. The lithic remains in archaeological contexts: studies, interpretation and applications")

Tricart, J. \& Vonfelt, J. 1955, La signification paleógeógraphique des conglomérats oligocènes de la bordure vosgienne. Bulletin du Service de la Carte Géologique d'Alsace et de Lorraine, 8(1): 105-118. (in French) ("Palaeogeographical meaning of the Oligocene Conglomerates of the Vosgienne edge")

Turq, A. 1989, Exploitation des matières premières lithiques et exploitation du sol: l'exemple du Moustérien entre Dordogne et Lot. Cahiers du Quaternaire, 13: 179-204. (in French) ("Lithic raw materials and land exploitation: the example of the Mousterian between Dordogne and Lot")

Turq, A. 2005, Réflexions méthodologiques sur les études de matières premières lithiques. Des litothèques au matériel archéologique. Paleo, 17: 11-132. (in French) ("Methodological reflections about lithic raw materials. From lithoteque to archaeological materials") URL: http://paleo.revues.org/883

Umeda, M. 2003, Precipitation of silica and formation of chert-mudstone-peat association in Miocene coastal environments at the opening of the Sea of Japan. Sedimentary Geology, 161: 249-268. doi:10.1016/S0037-0738(03)00117-9

Vaquero, M. 1997, Tecnología lítica y comportamiento humano: organización de las actividades técnicas y cambio diacrónico en el Paleolítico Medio del Abric Romaní (Capellades, Barcelona). Doctoral thesis at the Departament d'Història i Història de l'Art, Universitat Rovira i Virgili, Tarragona, 874 p. (in Spanish) ("Lithic technology and human behaviour: technical activities organization and diachronical change during the Middle Palaeolithic of the Abric Romaní (Capellades, Barcelona)") URL: http://www.tdx.cat/handle/10803/31930

Virgili, C. 1958, El Triásico de los Catalánides. Vol. 69. Boletín del Instituto Geológico y Minero de España. Instituto Geológico y Minero de España, Madrid, 492 p. (in Spanish) ("The Triassic of the Catalanides")

Whittle, G.L. \& Alsharhan, A.S. 1993, Dolomitization and chertification of the Early Eocene Rus Formation in Abu Dhabi, United Arab Emirates. Sedimentary Geology, 92: 273285. doi:10.1016/0037-0738(94)90110-4 